\title{
Ligands of Adrenergic Receptors: A Structural Point of View
}

\author{
Yiran $\mathrm{Wu}^{1}$, Liting Zeng ${ }^{1,2}$ and Suwen Zhao ${ }^{1,2, *}$ \\ 1 iHuman Institute, ShanghaiTech University, Shanghai 201210, China; wuyr@shanghaitech.edu.cn (Y.W.); \\ zenglt@shanghaitech.edu.cn (L.Z.) \\ 2 School of Life Science and Technology, ShanghaiTech University, Shanghai 201210, China \\ * Correspondence: zhaosw@shanghaitech.edu.cn
}

check for

updates

Citation: Wu, Y.; Zeng, L.; Zhao, S. Ligands of Adrenergic Receptors: A Structural Point of View. Biomolecules 2021, 11, 936. https://doi.org/ 10.3390/biom11070936

Academic Editor: Karsten Melcher

Received: 25 May 2021

Accepted: 12 June 2021

Published: 24 June 2021

Publisher's Note: MDPI stays neutral with regard to jurisdictional claims in published maps and institutional affiliations.

Copyright: (c) 2021 by the authors. Licensee MDPI, Basel, Switzerland. This article is an open access article distributed under the terms and conditions of the Creative Commons Attribution (CC BY) license (https:// creativecommons.org/licenses/by/ $4.0 /)$.

\begin{abstract}
Adrenergic receptors are G protein-coupled receptors for epinephrine and norepinephrine. They are targets of many drugs for various conditions, including treatment of hypertension, hypotension, and asthma. Adrenergic receptors are intensively studied in structural biology, displayed for binding poses of different types of ligands. Here, we summarized molecular mechanisms of ligand recognition and receptor activation exhibited by structure. We also reviewed recent advances in structure-based ligand discovery against adrenergic receptors.
\end{abstract}

Keywords: adrenergic receptor; adrenoreceptor; aminergic receptor; GPCR; activation mechanism; receptor-ligand interactions; selectivity; allosteric modulator; structure-based drug design

\section{Introduction}

Adrenergic receptors (adrenoreceptors, ARs) are membrane proteins mediating the actions of epinephrine and norepinephrine. Epinephrine and norepinephrine (also called $(-)$-adrenaline and (-)-noradrenaline, respectively) are neurotransmitters of the sympathetic nervous system and the central nervous system, and function as hormones secreted by the adrenal medulla. There are nine members of adrenergic receptors in humans (Figure 1a), widely distributed throughout the body and playing key roles in many important physiological processes, such as response to stress, control of heart rate and blood pressure, and regulation of metabolism [1-3]. Besides epinephrine and norepinephrine as emergency medicines, adrenergic receptors are also the target of many medications in treatment of various conditions, including hypertension, hypotension, heart failure, arrhythmias, and asthma [1,4]. In the 21st century, the development of new drugs against adrenergic receptors has slowed down, but the once most-neglected member $\beta_{3}$-adrenergic receptor is raising more attention than ever (Figure $1 b$ ).

The adrenergic receptors belong to the rhodopsin family/class A G protein-coupled receptors (GPCRs). The $\beta_{2}$-adrenergic receptor $\left(\beta_{2} \mathrm{AR}\right)$ is a prototype GPCR for studies of sequence, structure, and function: $\beta_{2} A R$ is the first GPCR cloned [5], the second GPCR was determined for atomic structure [6,7] (only after rhodopsin), and the first GPCR solved for the active state structure in a functional complex [8] (with $\mathrm{G}_{\mathrm{s}}$ protein heterotrimer). $\beta$-arrestins, the cytoplasmic partners responsible for desensitization of most GPCRs, were named after the $\beta_{2} \mathrm{AR}[9,10]$. Turkey $\beta_{1} \mathrm{AR}$ has been comprehensively studied in structural biology (in this article, all structure of $\beta_{1} A R$ refers to turkey $\beta_{1} A R$ unless noted). A complex of $\beta_{1} \mathrm{AR}$ and $\beta$-arrestin- 1 was reported in 2020 [11].

$\beta_{2} \mathrm{AR}$ and $\beta_{1} \mathrm{AR}$ are among the GPCRs with the largest numbers of structures obtained, providing rich information for ligand recognition and activation mechanisms $\left(\beta_{2} \mathrm{AR}\right.$ has 38 structures for 19 ligands and $\beta_{1}$ AR has 30 structures for 17 ligands). In 2019, structures of the three $\alpha_{2}$ adrenergic receptors were also reported, disclosing the structural basis for the receptor-type selectivity of ligands. In this review, we summarized current achievements of structural study in adrenergic receptors and advances in drug discovery based on these structures. 


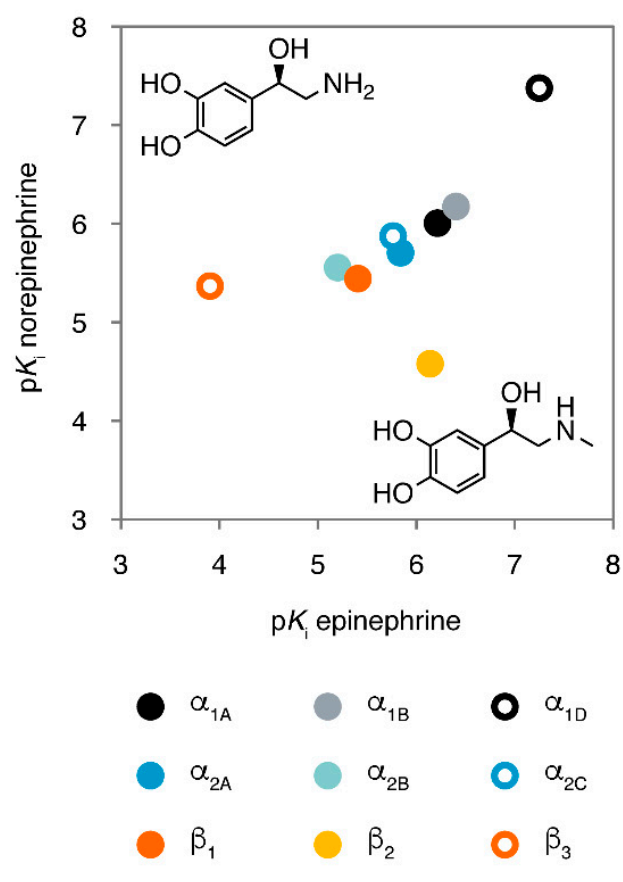

(a)
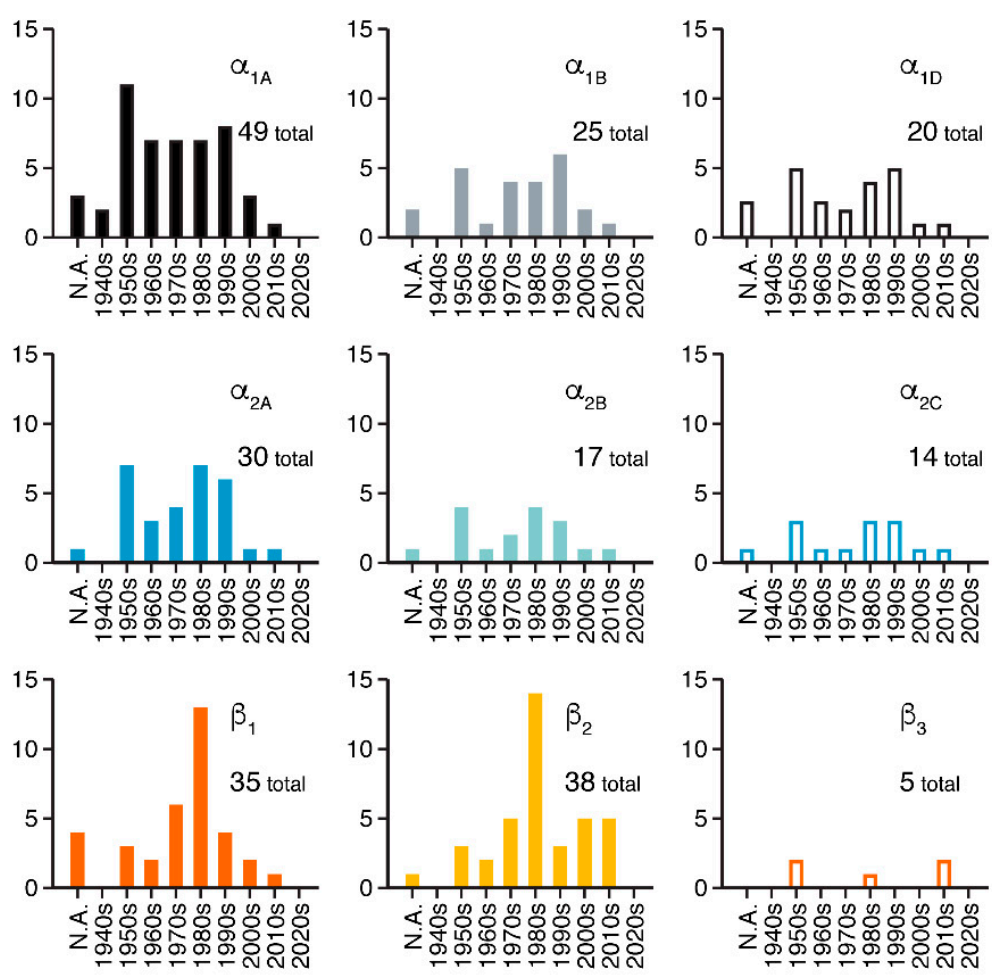

(b)

Figure 1. Adrenergic receptors as drug targets. (a) Binding affinities [12-14] of endogenous agonists in the nine adrenergic receptors. (b) Number of new drugs (approved or first marketing) for the nine adrenergic receptors in each decade. Data retrieved from Guide to PHARMACOLOGY [15] (www.guidetopharmacology.org, accessed on 25 April 2021), GPCRdb [16] (gpcrdb.org, accessed on 25 April 2021), and DrugBank [17] (go.drugbank.com, accessed on 25 April 2021).

\section{Adrenergic Receptors in the Aminergic Receptor Subfamily}

The nine adrenergic receptors in human body can be classified into three major types: $\alpha_{1}, \alpha_{2}$, and $\beta$, each having three subtypes. Members within a major type are highly similar in sequence and function, but in different major types are distinct in these aspects (see next section for detail). All the adrenergic receptors belong to the aminergic receptor subfamily, which has 42 members, forming a single clade in the phylogenetic tree of GPCRs [18-21]. The aminergic receptors bind monoamine neurotransmitters, acetylcholine, or trace amines, and share common features in sequence, structure, and function (Figure 2): in the orthosteric site (binding site of endogenous ligand), a conserved D3.32 (BallesterosWeinstein numbering, BWN [22]) forms a salt bridge to the positively charged amino group in ligand, and Y7.43 and W7.40 stabilize this salt bridge through a hydrogen bond and $\pi-\pi$ interactions (Figure $3 \mathrm{~b}$ ). Because of the shared ligand recognition mechanism, polypharmacology (drugs interacting with multiple targets) is common in aminergic receptors. For example, ergotamine (an alkaloid produced by fungus) can bind to 22 aminergic receptors with Ki less than $1 \mu \mathrm{M}$ [23]. Other notable cases include clozapine [24] and apomorphine [25]. Therefore, selectivity is a major concern in drug discovery against aminergic receptors.

The endogenous ligands of adrenergic receptors, epinephrine and norepinephrine, are monoamine neurotransmitters. Monoamine (also include dopamine, serotonin, and histamine) contains an amino group connected to an aromatic ring by a two-carbon chain (Figure $2 b$ ). When binding to receptors, the aromatic ring forms $\pi-\pi$ interactions to F6.51 and F6.52 (Figures 2a and 3b). Among the monoamines, dopamine is most similar to epinephrine and norepinephrine in chemical structure: each contains a catechol (1,2-dihydroxybenzene) group (thus collectively referred to as catecholamines). The catecholamines are products of three successive steps in the tyrosine metabolism pathway. Their 
receptors recognize the catechol hydroxy groups by S5.42 and S5.46 (Figures 2a and 3b), two serine residues in TM5 that appear in all members of adrenergic and dopamine receptors. These two positions are non-conserved in other aminergic receptors. Among the catecholamines, ligand-receptor recognition is not strictly specific: dopamine also acts on adrenergic receptors $[4,26,27]$, while epinephrine and norepinephrine are reported to stimulate some dopamine receptor subtypes $[28,29]$.

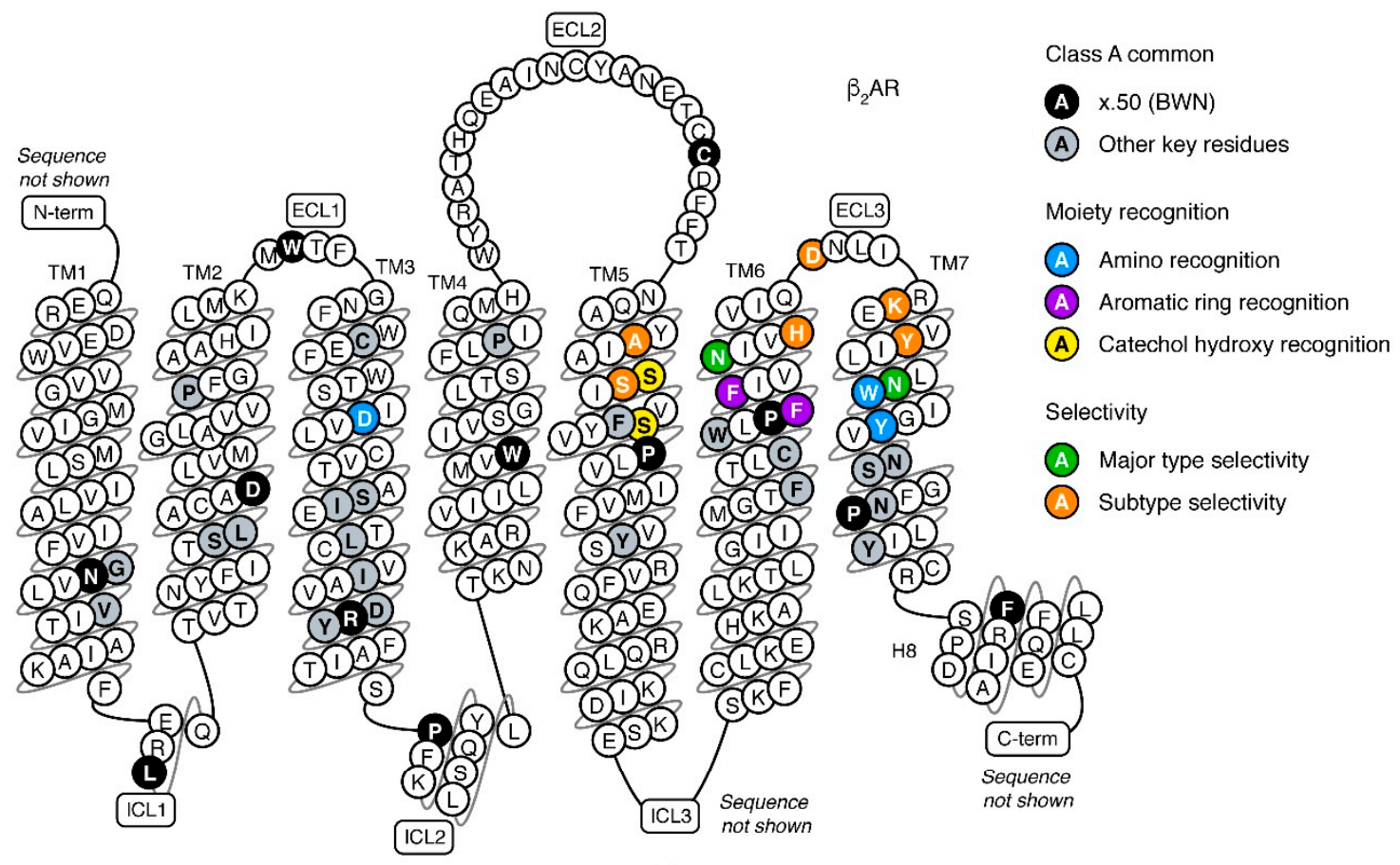

(a)

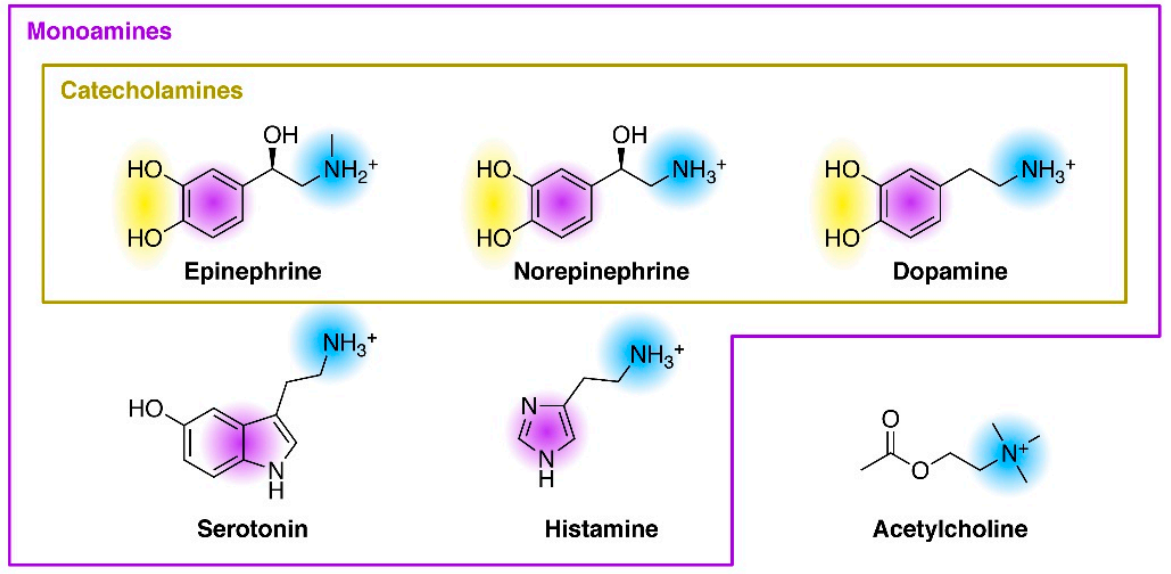

(b)

Figure 2. Mechanisms of ligand recognition by adrenergic receptors. (a) Key residues for protein structure maintaining, receptor activation, and endogenous ligand recognition, marked with color on snake plot of $\beta_{2}$ AR. x.50 are BallesterosWeinstein numbering (BWN) [22] of the most conserved residues in each segment. Sequence of N-terminus, ICL3, and C-terminus are not shown because these regions do not contain key residues and are very long. (b) Chemical structures of monoamine neurotransmitters (shown in protonated state) and acetylcholine. Moieties colored in consistent with interacting residues in panel (a). 


\section{Full-length}

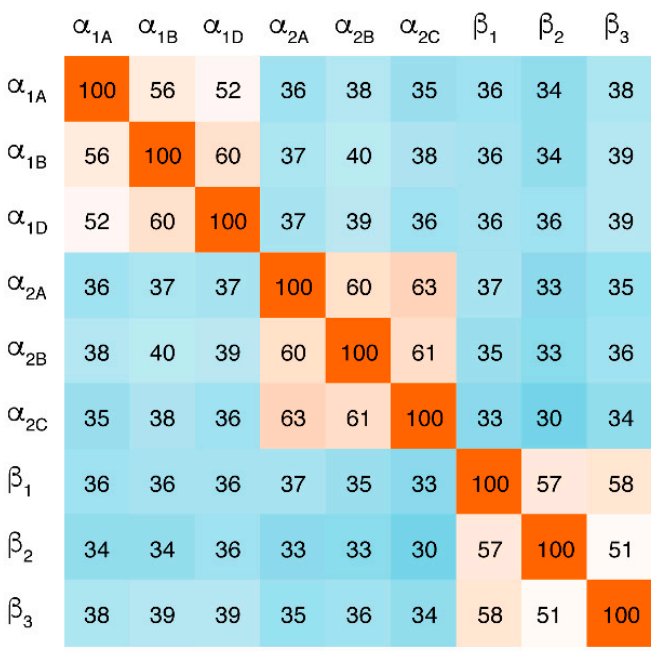

Pocket (33)

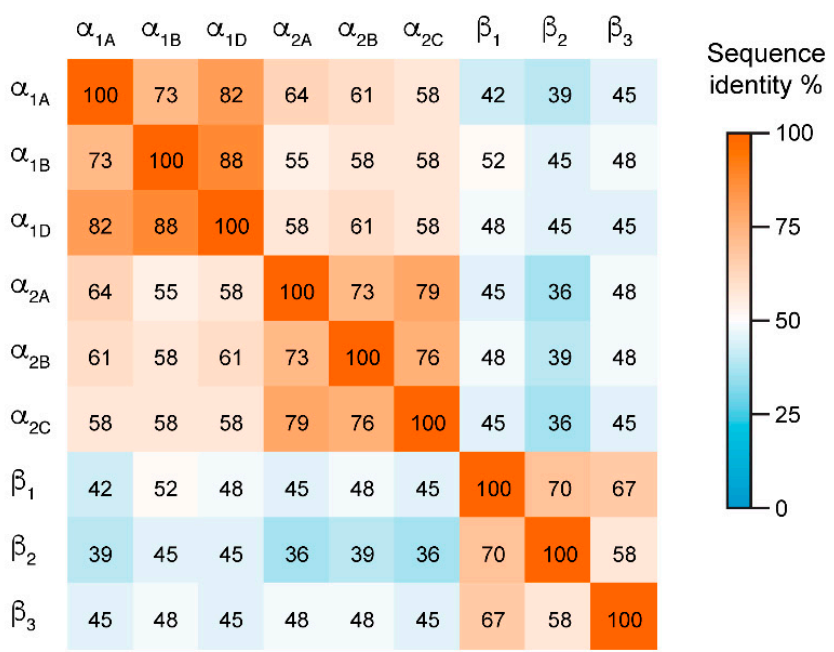

(a)

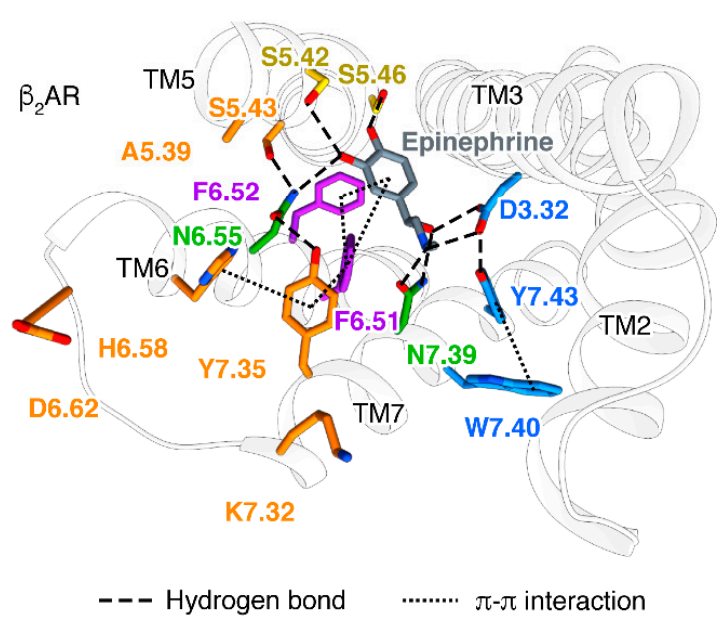

(b)

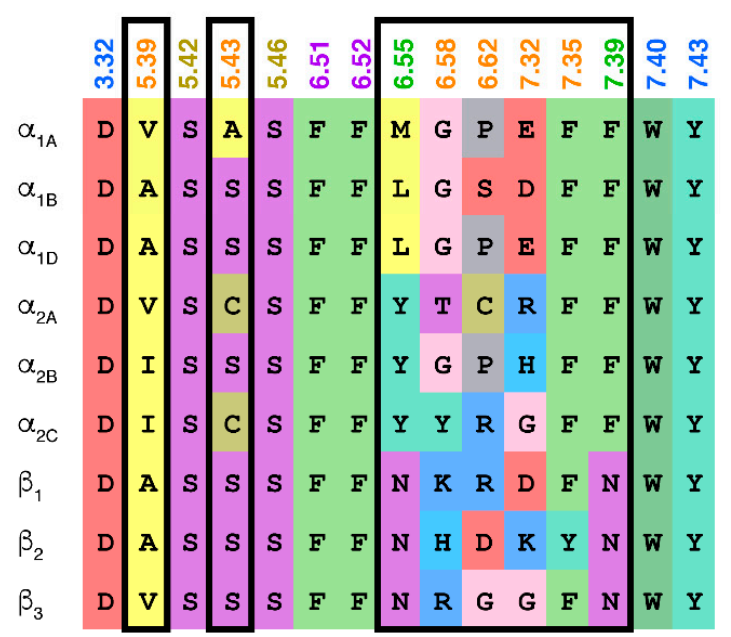

(c)

Figure 3. Comparison of adrenergic receptor major types and subtypes. (a) Sequence identity matrices of adrenergic receptors at full-length sequence (based on multiple sequence alignment generated with MAFFT v7.299b [30]) or pocket residues (33 residues: 2.61,64-65; 3.28-29,32-33,36-37; 45.50-54; 5.38-39,42-43,46; 6.48,51-52,55,58-59,62; 7.30,32,35-36,3940,43). 'Pocket' is the cavity at the extracellular side of a GPCR. (b) Key interactions of endogenous ligand epinephrine in orthosteric site of $\beta_{2} \mathrm{AR} /$ epinephrine (PDB: $4 \mathrm{LDO}$ [31], coloring scheme the same to Figure 2a). (c) Alignment of key residues for moiety recognition or type selectivity (residue BWN colored in the same scheme to Figures $2 \mathrm{a}$ and $3 \mathrm{~b}$ ) in all the adrenergic receptors members (generated from GPCRdb plot [16], residues colored for property: red, negatively charged; blue, positively charged; yellow, hydrophobic; blue, aromatic; magenta, hydrophilic; pink, glycine; gray, proline).

\section{Major Types and Subtypes of Adrenergic Receptors}

Adrenergic receptors are among the most studied GPCRs. Research on their roles in sympathetic nerve stimulation started at the beginning of the 20th century. In the premolecular biology era, major types and subtypes of adrenergic receptors were identified through their pharmacological characteristics and tissue locations. All the nine members were cloned by the early 1990s, before the human genome project was completed [1,32].

Major types largely correspond to the sequences and functions of adrenergic receptors. Members within a major type share 51-64\% sequence identities at full-length, while in different major types, the values decrease to $30-40 \%$ (Figure $3 a$ ). This is the basis: adrenergic receptors in each major type have similar affinities for many ligands and mainly couple to a specific $G$ protein type (Table 1 ). Notably, pocket residues of $\alpha_{1}$ ARs and $\alpha_{2}$ ARs are 
more similar, thus they share some ligands that do not target $\beta$ ARs. For the distinct cell and tissue responses of adrenergic receptors, medications targeting different major types have different indications (Table 1). Two residues at the ligand binding site, 6.55 [33] and 7.39 [34], are reported to affect the major type selectivity of ligands (Figures 2a and 3b,c).

Even within a major type, adrenergic receptor subtypes may have distinct effects, due to their tissue distribution. This is exhibited in the $\beta$ adrenergic receptors: $\beta_{1} A R$ is mainly expressed in heart and adipose tissue, thus its activation produces cardiac stimulation and increased lipolysis; $\beta_{2} \mathrm{AR}$ is ubiquitously expressed but with high levels in the smooth muscle, especially of the airway, thus its main effect is bronchodilation; and $\beta_{3} A R$ is mainly expressed in adipose tissue, thus is responsible for increased lipolysis [35]. Therefore, while using $\beta$ antagonists to treat cardiovascular diseases, $\beta_{1}$-selective agents have less asthma adverse effects than non-selective agents [36]. $\beta_{3}$-selective agonists are widely investigated as anti-obesity agents, though they still face many challenges [37]. The benefits of subtype-selective drugs are also found in the other two major types: $\alpha_{1 \mathrm{~A}} / \alpha_{1 \mathrm{D}}$ selective antagonist tamsulosin has less impact on blood pressure while treating benign prostatic hyperplasia [38]; and $\alpha_{2 C}$ selective antagonists are in development as potential treatments for multiple psychiatric diseases [39]. Positions 5.39 [40], 5.43 [41], 6.58 [42], 6.62 [43] (ECL3), 7.32 [42], and 7.35 [44,45] are reported to affect the subtype selectivity of ligands. These residues are at the extracellular edge of the pocket (Figures $2 a$ and $3 b, c)$.

Table 1. Major types of adrenergic receptors.

\begin{tabular}{|c|c|c|c|c|}
\hline Major Type & Primary Pathway & Main Effects & Indications of Agonists & Indications of Antagonists \\
\hline$\alpha_{1}$ & $\mathrm{G}_{\mathrm{q} / 11}$ & smooth muscle contraction & $\begin{array}{l}\text { vasodilatory shock, } \\
\text { hypotension [46] }\end{array}$ & $\begin{array}{l}\text { hypertension, benign prostatic } \\
\text { hyperplasia [47] }\end{array}$ \\
\hline$\alpha_{2}$ & $\mathrm{G}_{\mathrm{i} / \mathrm{o}}$ & $\begin{array}{l}\text { inhibition of norepinephrine } \\
\text { release }\end{array}$ & $\begin{array}{c}\text { hypertension, } \\
\text { pain and panic disorders [48] }\end{array}$ & $\begin{array}{l}\text { erectile dysfunction [49], } \\
\text { depression [50] }\end{array}$ \\
\hline$\beta$ & $\mathrm{G}_{\mathrm{s}}$ & $\begin{array}{c}\beta_{1}: \text { cardiac stimulation } \\
\beta_{2}: \text { bronchodilation } \\
\beta_{3}: \text { increased lipolysis }\end{array}$ & $\begin{array}{l}\text { cardiogenic shock, heart } \\
\text { failure, asthma, overactive } \\
\text { bladder [4] }\end{array}$ & $\begin{array}{l}\text { heart failure, arrhythmias, } \\
\text { hypertension [51] }\end{array}$ \\
\hline
\end{tabular}

\section{Mechanisms of $\beta$ Adrenergic Receptors}

\subsection{Activation Mechanism}

For a class A GPCR, the most significant conformational changes during activation are of the outward movement of the cytoplasmic end of TM6 and rearrangement of TM7 (Figure 4a). About 90 receptors [52] share a common mechanism: the conformational changes are mediated by the microswitch of the P5.50-I3.40-F6.44 motif, induced by an agonist. How agonists trigger the microswitch of the P-I-F motif largely varies in different receptor families. For $\beta_{2} \mathrm{AR}$ or $\beta_{1} \mathrm{AR}$, an agonist forms a hydrogen bond to S5.46, thus pulling TM5 closer to TM3/6. An antagonist, in contrast, lacks this hydrogen bond and tends to occupy the space with hydrophobic moiety, thus preventing the movement of TM5 (Figure $4 b$ ). This mechanism is presented in all $\beta_{2} / \beta_{1}$ agonists and antagonists (Figure $4 c$, representative ligands are listed in Table S1).

Binding of the orthosteric agonist and coupling of $G$ protein have an effect on each other: agonists have higher affinities in $\beta_{2} A R$ with the presence of $G$ protein than in the absence of $G$ protein [53]. Structure studies of agonists binding in different states of $\beta_{1} \mathrm{AR}$ disclosed the molecular basis: active state structures have smaller pockets when comparing to agonist-bound inactive state structures (Figure 4d) [54]. Inferred from the mechanism, antagonists tend to fit in more expanded orthosteric pockets. This was established in different types of class A GPCRs, including lipid receptors [55-58], peptide receptors [59-61], and nucleotide receptors [62-65]. 


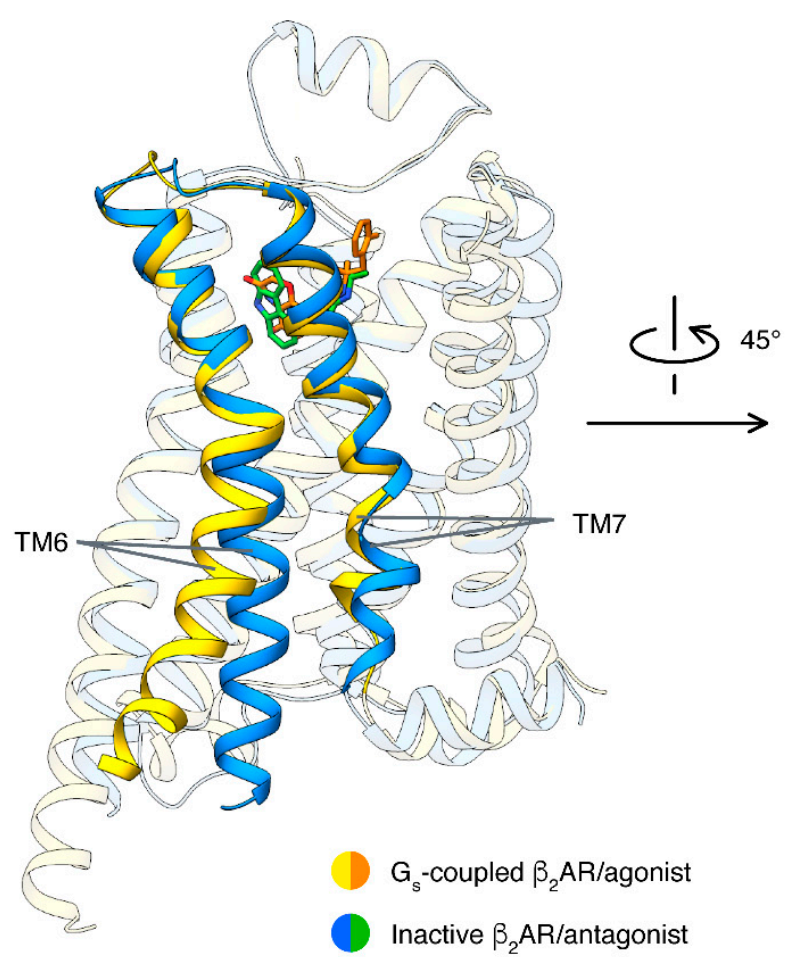

(a)

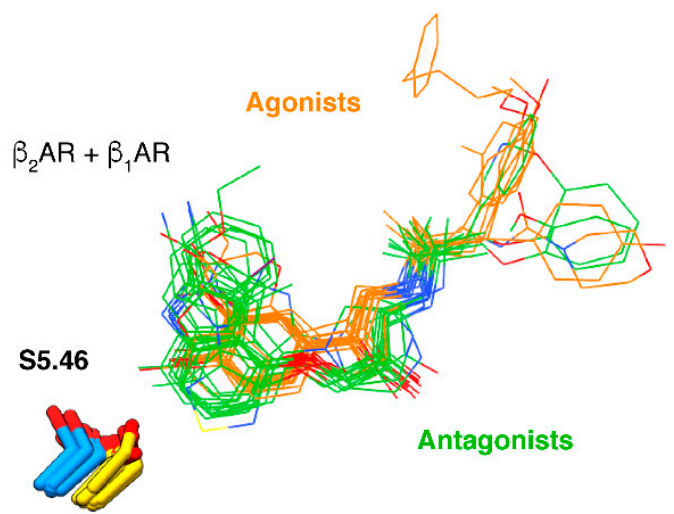

(c)

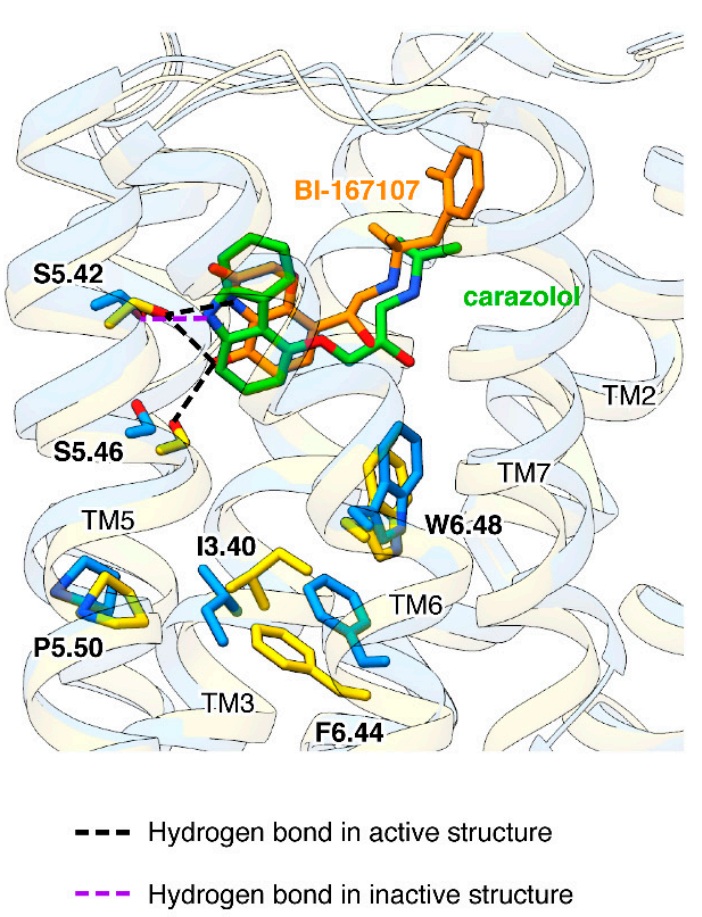

(b)

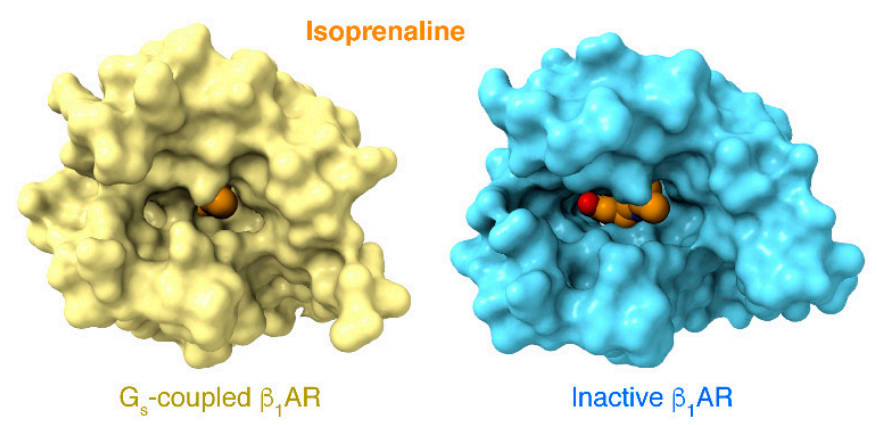

(d)

Figure 4. Mechanism of agonism in $\beta$ adrenergic receptors. (a) Structures of $\beta_{2} A R$ in active/inactive states (PDB IDs: 3SN6 [8], 2RH1 [6]). (b) Interactions of agonist/antagonist to S5.42/S5.46 and microswitch of P5.50-I3.40-F6.44 motif. (c) Binding poses of agonists/antagonists in $\beta_{1} \mathrm{AR} / \beta_{2} \mathrm{AR}[6,8,11,31,43,54,66-77]$. Structures were aligned based on $\mathrm{C} \alpha$ atoms of 7 residues: $3.32 ; 5.42,46 ; 6.51-52 ; 7.40,43$. (d) Binding poses of isoproterenol in $\beta_{1}$ active/inactive states (PDB IDs: 7JJO [66], 2Y03 [67]).

\subsection{Biased Signaling}

Some agonists stimulate the $\beta$-arrestin signaling with higher or lower $\mathrm{EC}_{50}$ comparing to the $G$ protein signaling (called biased signaling). For $\beta$ ARs, separately targeting $\beta$-arrestin pathways or $G$ protein pathways is considered a therapeutic potential for diseases, including heart failure and asthma [78,79]. Structures of GPCR in complex with arrestin have been obtained in several receptors [80-83] including $\beta_{1} A R$ [11]. Compared to $G_{\text {s }}$-coupled $\beta_{1} A R$, arrestin-coupled $\beta_{1} A R$ adopts a smaller degree of outward movement of TM6 and additional twist of TM7 (Figure 5a). Correspondingly, $\beta_{1}$ AR forms interactions to arrestin with more residues in TM2/7 and fewer residues in TM5/6 [11,66]. In accordance with this, NMR experiments of ${ }^{19} \mathrm{~F}$-labeling on the cytoplasmic ends of TM6 and TM7 showed that arrestin-biased agonists induce more conformational change of TM7 
than of TM6 for $\beta_{2} \mathrm{AR}$ in solution [84]. Structures showed that arrestin-biased agonists carvedilol [85], bucindolo [86], formoterol [87], and BI-167107 [88] have an aryl-substituted alkyl tail attached to the amino $\mathrm{N}$ atom, and the bulky aromatic rings occupy an extended pocket formed by TM2/3/7 and ECL2 in $\beta_{2} \mathrm{AR}$ or $\beta_{1} \mathrm{AR}[8,11,41,66,75,89,90]$ (Figure 5). In contrast, $\mathrm{G}_{\mathrm{s}}$-biased agonist salmeterol occupies this space but forms distinct interactions with a long aryloxyalkyl tail [70]. However, there are also mysteries of arrestin-biased signaling: an approved $\beta$ agonist drug, isoetharine, is arrestin-biased in $\beta_{2} \mathrm{AR}$ [91] but $\mathrm{G}_{\mathrm{s}}$-biased in $\beta_{1} \mathrm{AR}$ [92]. The structural mechanism remains to be explored.

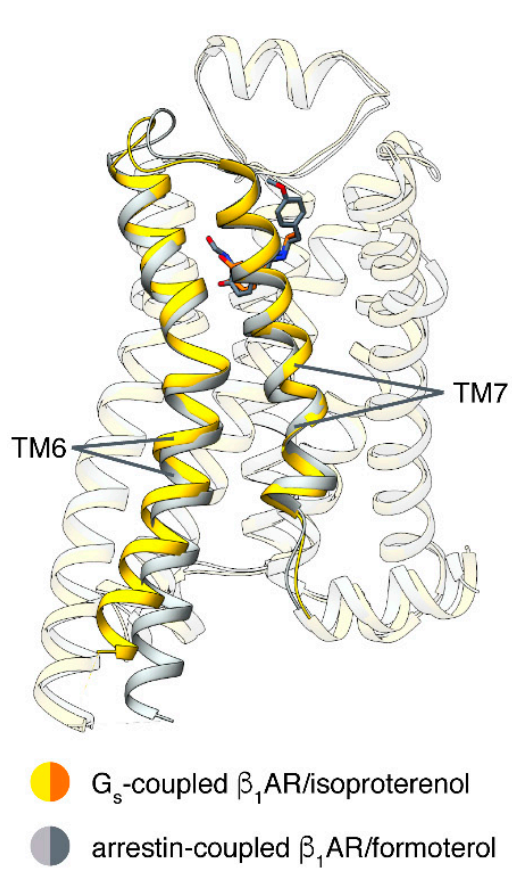

(a)

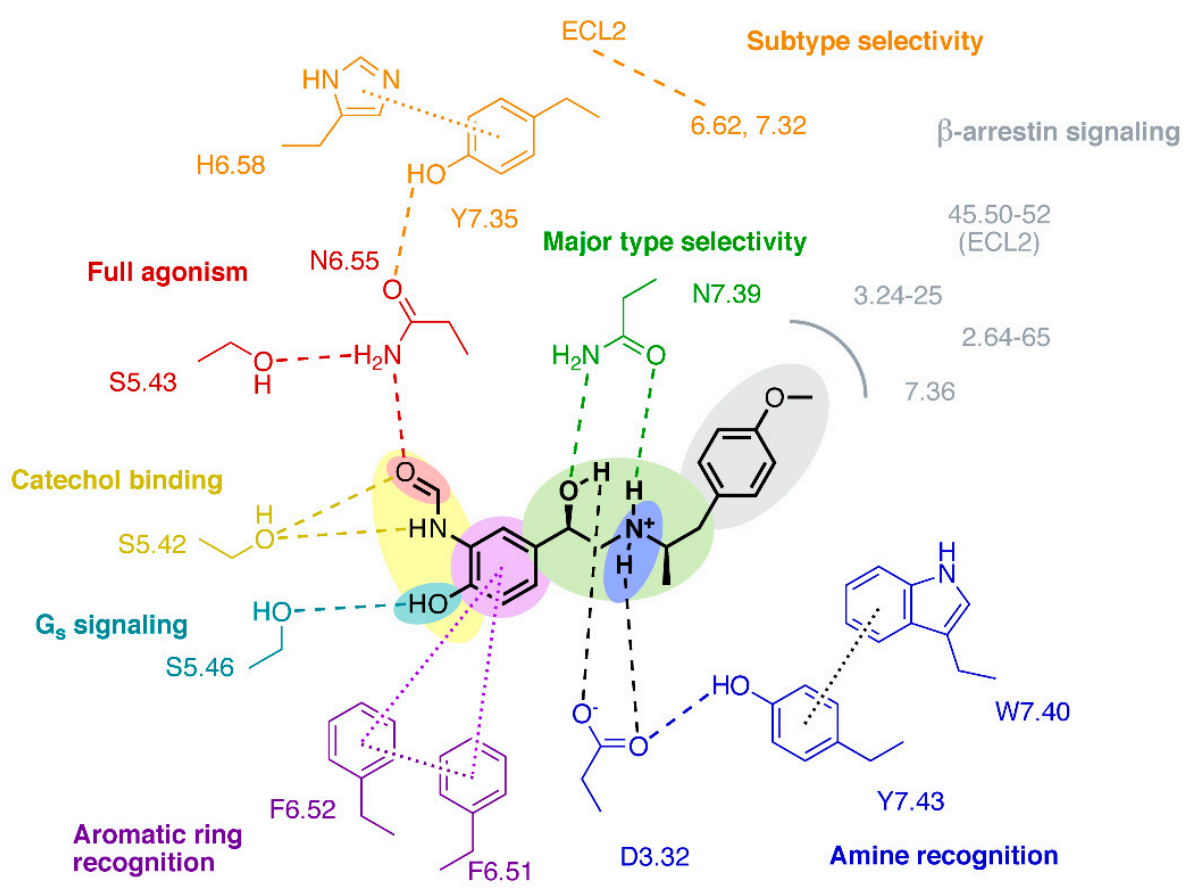

(b)

Figure 5. Mechanisms of effects of ligands on $\beta$ adrenergic receptors. (a) Structures of $\beta_{1} A R$ coupled to $G_{s}$ or arrestin (PDB IDs: 7JJO [66], 6TKO [11]) (b) Sketch map of key ligand interactions in $\beta$ ARs. Formoterol in $\beta_{2}$ AR was used for the drawing.

\subsection{Partial Agonism}

Many $\beta$ ARs ligands in clinical use are partial agonists, which do not produce a full response, even at high concentration. NMR [84,93,94], single-molecule fluorescence resonance energy transfer [95], and double electron-electron resonance [94,96] results showed that partial agonists induce a smaller shift of conformational equilibrium of TM6, compared to full agonists. A well-identified key interaction affecting ligand efficacy (ratio of maximal response of the ligand to full response) is a hydrogen bond to N6.55 by a full agonist, but not a partial agonist (Figure 5b). Mutations of N6.55 and S5.43 (which forms hydrogen bond to N6.55) in $\beta_{2} A R$ reduce the efficacy of full agonist isoproterenol, strongly supporting that this hydrogen bond network is crucial to the full activation of $\beta$ ARs [70]. All full agonists can form a hydrogen bond to N6.55, either by 3-hydroxy in catechol (like epinephrine [31,43] or isoproterenol [54,66]) or groups mimicking catechol (such as formoterol [11] or BI-167107 [8,43,90]). Most partial agonists cannot form this hydrogen bond for replacement of the 3-hydroxy, including salmeterol [70], salbutamol [54,69], xamoterol [54], and clenbuterol. However, this cannot explain dobutamine, a partial agonist of $\beta_{1} A R$ and $\beta_{2} A R$, reserving the catechol moiety and forming a hydrogen bond with N6.55 [54]. Therefore, there may be other receptor-ligand interactions affecting ligand efficacy to be discovered. NMR experiments showed that in $\beta_{2} A R$, the chemical shift of M2.53 depends on the efficacy of the ligand [97], and dobutamine's direct contact with 
TM2 (at 2.61, 2.64, and 2.65). Whether this is the basis of partial agonism of dobutamine remains to be investigated.

\section{4. $\beta_{1} / \beta_{2}$ Subtype Selectivity}

$\beta_{1} \mathrm{AR}$ and $\beta_{2} \mathrm{AR}$ are highly similar in sequence (identity $57 \%$ at full-length and $70 \%$ at pocket residues) and structure (root mean square deviation $0.71 \AA$ for inactive state and $1.00 \AA$ for $\mathrm{G}_{\mathrm{s}}$-coupled active state). Despite their high homology, numerous agonists and antagonists selective for $\beta_{1} A R$ or $\beta_{2} A R$ have been discovered. Even endogenous agonist norepinephrine, small in size, thus all the interacting residues are the same in the two receptors, is approximately 10 -fold selective for $\beta_{1} \mathrm{AR}$ (while the other endogenous ligand epinephrine, with only one extra methyl group, is nonselective). Revealing of the molecular mechanisms of $\beta_{1} / \beta_{2}$ subtype selectivity began only recently.

In $\beta_{1} A R$ and $\beta_{2} A R$, although all the residues at the orthosteric site are the same, some residues at the edge of the pocket are different. Large ligands may directly interact with these residues. For example, salmeterol ( $>1000$-fold selective for $\left.\beta_{2} A R\right)$ has a long aryloxyalkyl tail, forming additional interactions to TM2, TM3, TM7, ECL2, and ECL3. Three of the interacting residues, while mutated to the corresponding residue in $\beta_{1} A R$ (H6.58N, K7.32D, and Y7.35F), largely reduce the affinity of salmeterol [70]. Residues at ECL2 and the extracellular end of TM6/7 sculpt the different shapes of pocket entrances in the two $\beta$ adrenergic receptors: in $\beta_{2} \mathrm{AR}, \mathrm{K} 7.32$ forms a salt bridge to D45.51, covering the space among TM2/3/7; and in human $\beta_{1} \mathrm{AR}$, a different salt bridge is formed by R6.62 to E205 (ECL2), covering the space among TM3/5/6. Therefore, ligands potentially take different paths to enter $\beta_{1} A R$ and $\beta_{2} A R$. The passage in $\beta_{1} A R$ is continuously negatively charged, thus preferred by norepinephrine, while epinephrine, a secondary amine, is less affected. This hypothesis explains the fast association rate of norepinephrine in $\beta_{1} A R$ and is supported by free energy profiles, calculated using metadynamics simulations [43].

\section{Mechanisms of $\alpha_{2}$ Receptors}

\subsection{Ligand Binding}

Structures of $\alpha_{2 A} A R$ [98] and $\alpha_{2 C} A R$ [99] in an inactive state and $\alpha_{2 B} A R$ [52] in an active state are disclosed. The binding of both agonist and antagonist in $\alpha_{2}$ adrenergic receptors involves more $\pi-\pi$ or cation $-\pi$ interactions and fewer hydrogen bonds (Figure $6 \mathrm{a}, \mathrm{b}$ ), comparing to $\beta$ ARs (Figure $3 b$ ). The expansion of $\pi$ interaction network is mainly caused by F7.39, conserved in all $\alpha_{1}$ ARs and $\alpha_{2}$ ARs but is N7.39 in $\beta$ ARs. In the agonist-bound structures, F7.39 acts as a 'lid', covering the imidazole ring of ligand from the extracellular side (Figure 6c). Typical $\alpha$ agonists and some $\alpha$ antagonists contain positively charged planar groups, such as imidazole, imidazoline, and guanidine [100], which fit well in this closed pocket. In inactive structures, the 'lid' F7.39 is pushed up to another rotamer by antagonist (Figure $6 \mathrm{~d}$ ), making the pocket larger, thus able to accommodate bulky ligands. Some $\alpha$ ligands with such chemical features are in clinical use, including piperazine derivatives as $\alpha_{1}$ antagonists (e.g., prazosin) and indole alkaloids with multiple fused rings as $\alpha_{2}$ antagonists (e.g., yohimbine). 


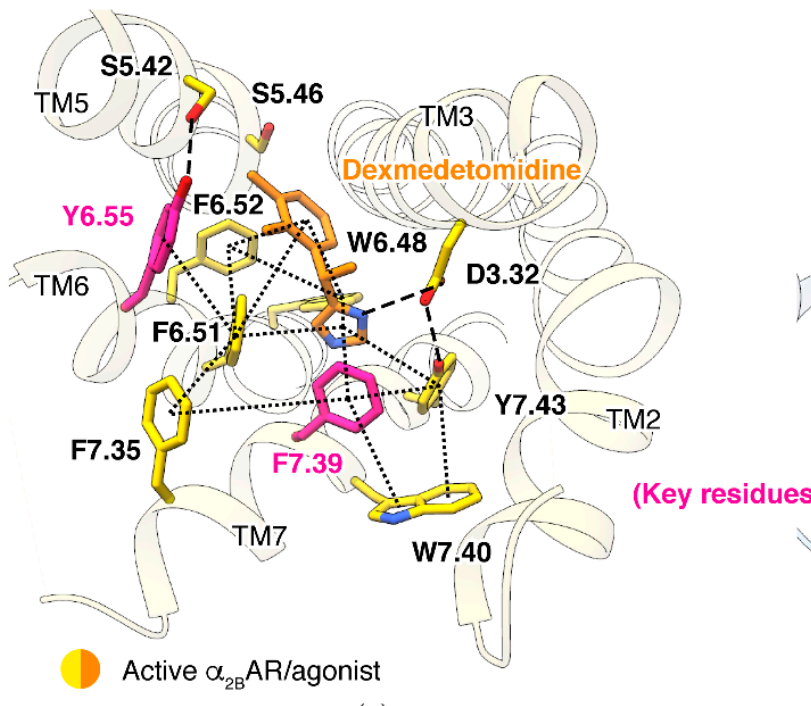

(a)

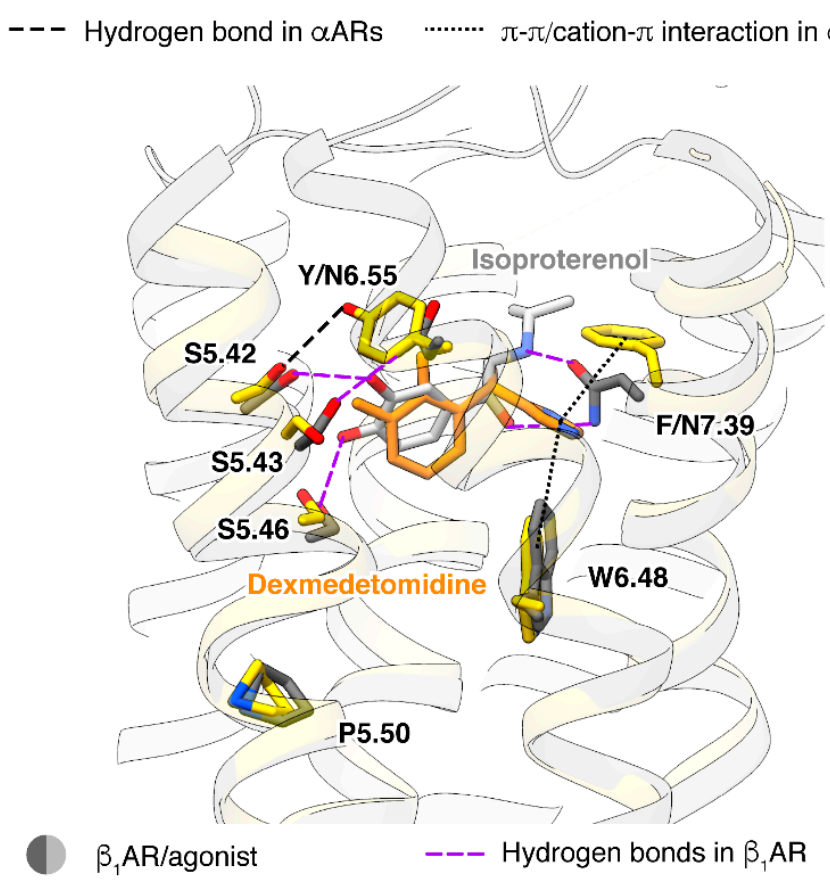

(c)

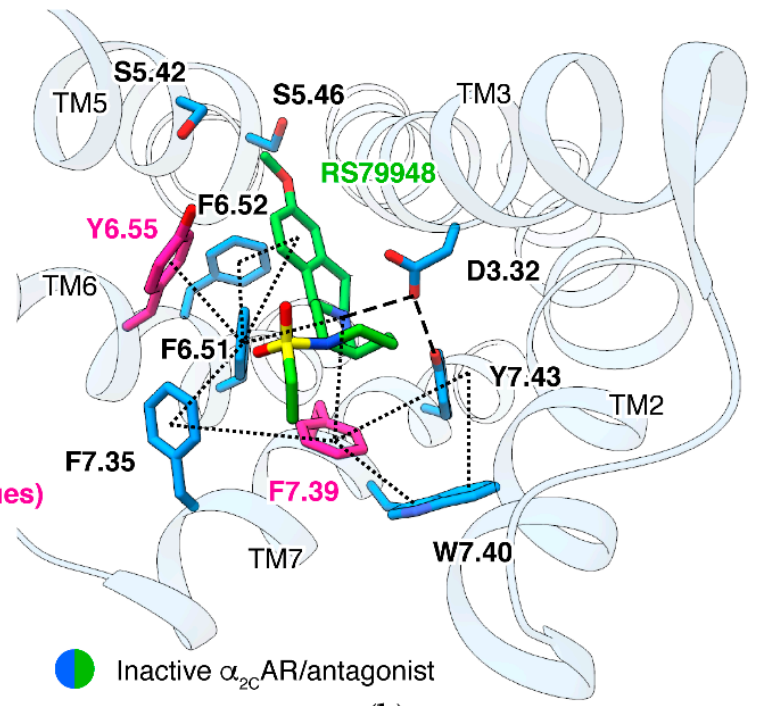

(b)

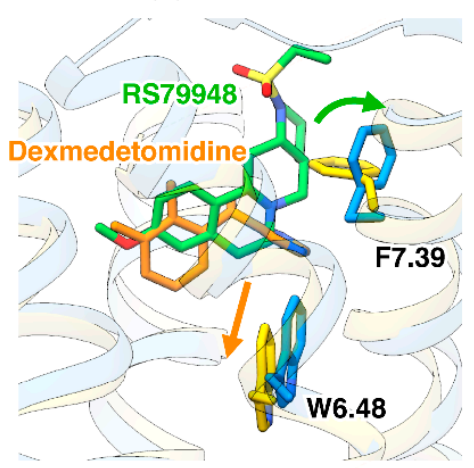

(d)

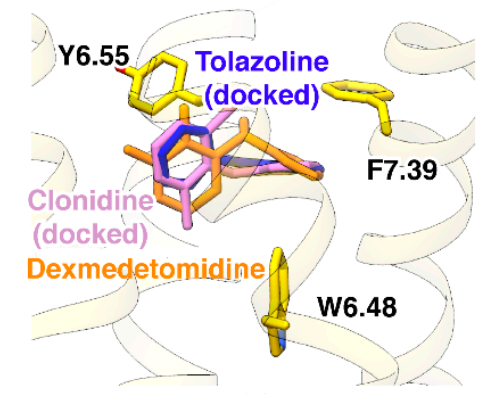

(e)

Figure 6. Mechanisms in $\alpha_{2}$ adrenergic receptors. (a) Agonist recognition (dexmedetomidine in $\alpha_{2 B}$ AR, PDB ID: 6K41 [52]). (b) Antagonist recognition (RS 79948 in $\alpha_{2 C}$ AR, PDB ID: 6KUW [99]). (c) Comparison of agonist recognition in $\alpha_{2}$ ARs and $\beta$ ARs (isoproterenol in $\beta_{1}$ AR, PDB ID: 6H7J [54]). (d) Conformational changes in active/inactive $\alpha_{2}$ ARs. (e) Binding poses of agonist clonidine and antagonist torazoline, predicted by molecular docking (Glide program in Schrodinger platform 2019-2 [38]).

\section{2. $\alpha / \beta$ Selectivity}

The binding of $\alpha$ agonists and antagonists relies on $\pi$ interactions involving F7.39, thus, is not favored in $\beta$ ARs with N7.39. $\beta$ ligands, instead, largely prefer to retain ethanolamine moiety [101] to form dual hydrogen bonds to N7.39 (Figure 6c). Another feature of $\beta$ ligands is a single large substituent on the amino $\mathrm{N}$ atom. A large group at this position is not favored in $\alpha \mathrm{ARs}$ as it is too large to fit in the closed pocket and too flexible to trigger the 'switching lid'. Only one substitution is allowed because only primary and secondary amines can form a hydrogen bond to N7.39 in $\beta$ ARs. This is validated by the polypharmacology profile of ergotamine, a tertiary amine: the binding affinities 
are $0.3-3 \mathrm{nM}$ in $\alpha_{2} \mathrm{ARs}, 10-30 \mathrm{nM}$ in $\alpha_{1} \mathrm{ARs}$, and $\sim 100 \mathrm{nM}$ in $\beta_{2} \mathrm{AR}$ and $>10,000 \mathrm{nM}$ in $\beta_{1} \mathrm{AR} / \beta_{3} \mathrm{AR}[23]$.

\subsection{Alternative Activation Mechanism}

Activation of $\beta_{1} A R / \beta_{2} A R$ requires an agonist forming a hydrogen bond to S5.46. In $\alpha_{2}$ ARs, the catecholamine agonists can form this hydrogen bond, but many $\alpha_{2}$ agonists, including dexmedetomidine and clonidine, do not have polar groups at this position. Mutation S5.42A or S5.46A in $\alpha_{2 \mathrm{~A}} \mathrm{AR}$ reduce the activation of epinephrine, but not of dexmedetomidine and clonidine [102]. Structures show that dexmedetomidine activates $\alpha_{2 B}$ by forming $\pi-\pi$ interactions to W6.48 and pushing it downward (Figure $6 \mathrm{~d}$ ). The downward movement of W6.48 is part of the common activation mechanism in class A GPCRs (Figure 4a). To effectively push W6.48, the ligand must compactly fill the pocket. This mechanism explains the functions of imidazole/imidazoline derivatives as $\alpha_{2}$ drugs: dexmedetomidine and clonidine are agonists for they fill the pocket, while tolazoline, without substituents on the benzen ring, thus being smaller in size, is an antagonist (Figure 6e). This series of imidazole/imidazoline derivatives is a special case in GPCR ligands, as normally, antagonists are larger than agonists because the pocket of inactive state is larger.

\subsection{Pathway Selectivity}

Position 6.55 is the only one in the orthosteric site that each major type of adrenergic receptor has a residue with a specific property: $\alpha_{1}$ ARs, hydrophobic M6.55 $\left(\alpha_{1 \mathrm{~A}} \mathrm{AR}\right)$ or L6.55 ( $\left.\alpha_{1 \mathrm{~B}} \mathrm{AR} / \alpha_{1 \mathrm{D}} \mathrm{AR}\right) ; \alpha_{2} \mathrm{ARs}$, aromatic Y6.55; $\beta$ ARs, polar N6.55. Interestingly, Y6.55 in $\alpha_{2}$ ARs shows a distinct impact on different downstream pathways: $\alpha_{2}$ ARs mainly functions through the $G_{i}$ pathway, but they also couple to $G_{s}$. Mutation $Y 6.55 \mathrm{~N}$ demolishes $\mathrm{G}_{\mathrm{s}}$ signaling but retains $\mathrm{G}_{\mathrm{i}}$ signaling in $\alpha_{2 \mathrm{~A}} \mathrm{AR}$, suggesting that this residue has a subtle impact on receptor conformation [98]. In both active and inactive structures of $\alpha_{2}$ ARs, Y6.55 lies horizontally, and forms van der Waals interactions with ligands from the extracellular site. In active state $\alpha_{2 B} A R, Y 6.55$ forms a hydrogen bond with S5.42 (Figure 6a). This hydrogen bond may be comparable to the hydrogen bond between N6.55 and S5.43 in $\beta$ ARs, while N6.55 and S5.43 affect the efficacy of agonists [70]. Structures also exhibit other possible roles of Y6.55: first, Y6.55 defines the upper boundary of the pocket (Figure 6e), thus rejecting many $\beta$ ligands with large groups at the catechol recognizing side (e.g., formoterol and carvedilol); second, Y6.55 blocks the TM3/5/6 space, leaving TM2/3/7 the only passage for ligands. This might be the basis for both epinephrine and norepinephrine having similar affinities in all three $\alpha_{2}$ adrenergic receptors $[13,43]$.

\section{5. $\alpha_{2 A} / \alpha_{2 C}$ Subtype Selectivity}

$\alpha_{2}$ ARs are highly similar in sequence, but there are still $\alpha_{2}$ ligands with high subtype selectivity. The molecular docking of two $\alpha_{2 C}$ antagonists JP1302 (100 folds selectivity to $\alpha_{2 \mathrm{~A}} \mathrm{AR}, 50$ folds to $\alpha_{2 \mathrm{~B}} \mathrm{AR}$ [103]) and OPC-28326 (300 folds to $\alpha_{2 \mathrm{~A}} \mathrm{AR}, 50$ folds to $\alpha_{2 \mathrm{~B}} \mathrm{AR}$ [104]) suggested that the two compounds, large and long, interact with nonconserved extracellular residues. Mutagenesis showed that an interaction network among Y6.58 (unique to $\alpha_{2 C} \mathrm{AR}$ ), R6.62, and D45.54 are key to the functions of JP1302 and OPC28326, while in $\alpha_{2 A} A R$, mutations of a different interaction network involving R7.32 (unique to $\alpha_{2 \mathrm{~A}} \mathrm{AR}$ ) restore their functions [99]. Such impact of extracellular residues on subtype selectivity is comparable to the $\beta_{1} / \beta_{2}$ selectivity case.

\section{Allosteric Modulations of $\beta_{2}$ Adrenergic Receptor}

In a GPCR, a ligand may bind outside the orthosteric site and stabilize a specific state, and this phenomenon is called allosteric modulation [105,106]. An allosteric ligand increasing the signaling of orthosteric agonists is a positive allosteric modulator (PAM), and one decreasing the signaling is a negative allosteric modulator (NAM). Allosteric modulators have raised attention in drug discovery against GPCRs because targeting 
less-conserved allosteric sites may produce subtype selectivity. The most effective way to identify an allosteric site is determining the structure of the GPCR in complex with the allosteric modulator [107]. Structures of $\beta_{2}$ AR captured small molecules binding at different sites and exhibited how they affect the signaling (Figure 7). The cholesterol binding sites were thoroughly reviewed recently [108], thus is not discussed here.

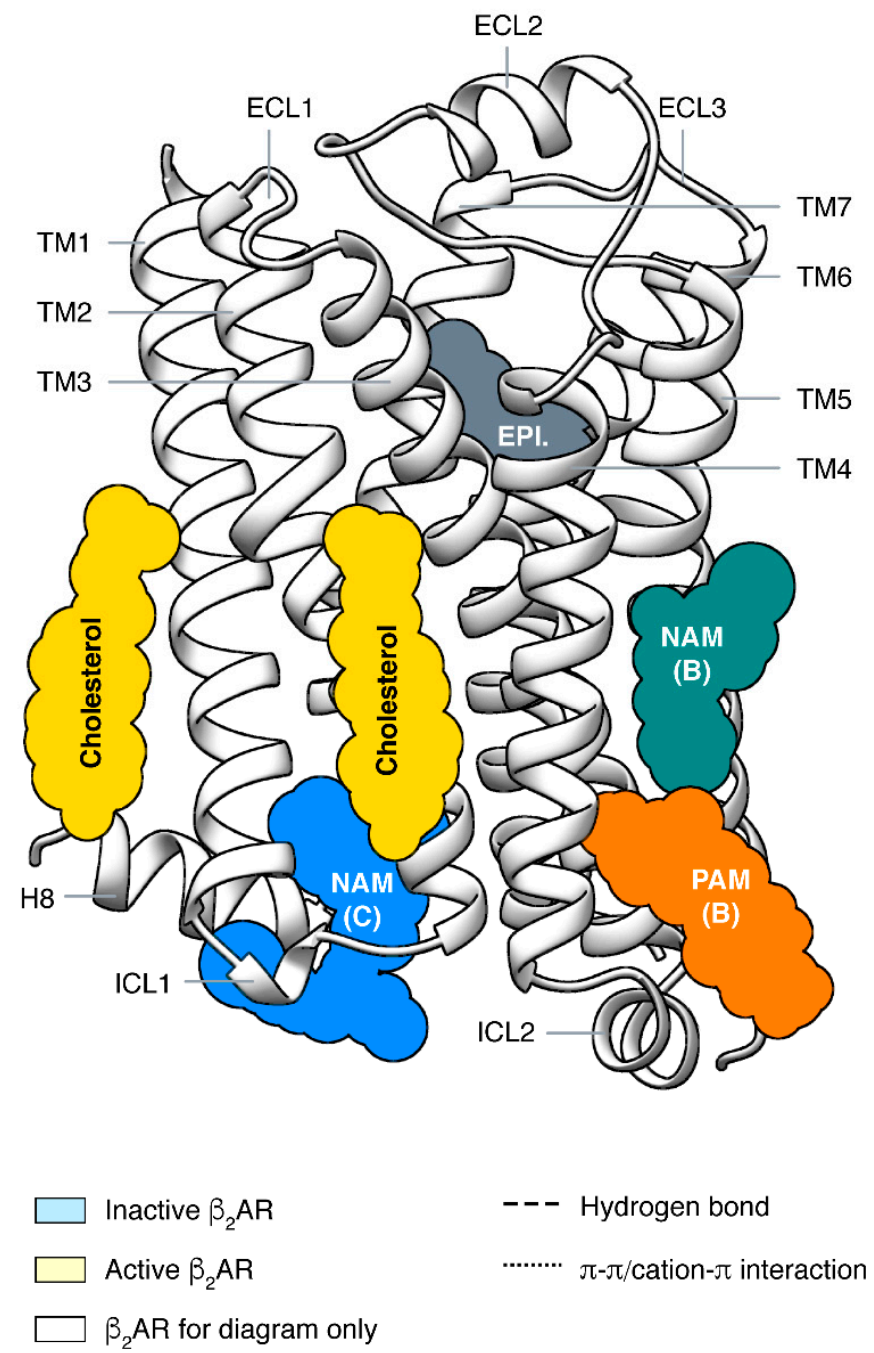

(a)

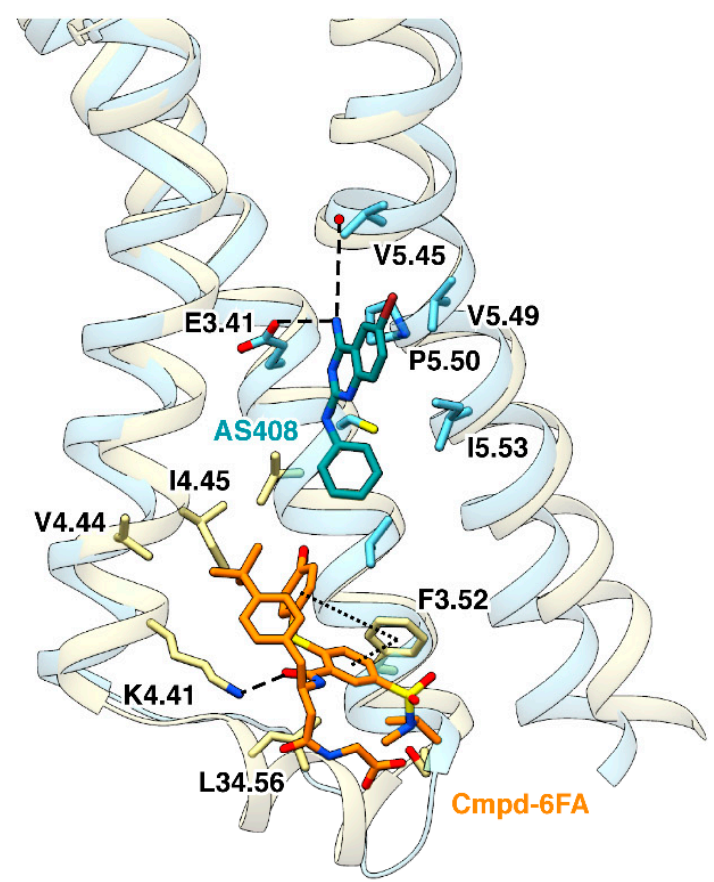

(b)

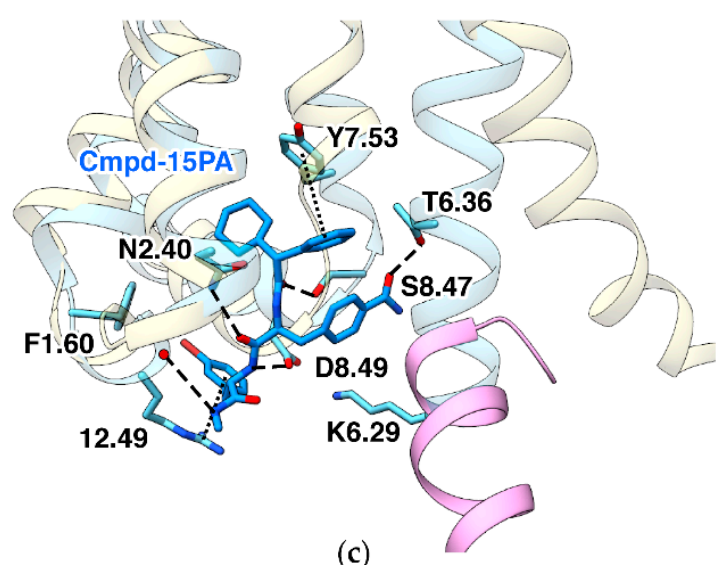

(c)

Figure 7. Allosteric modulating of $\beta_{2}$ AR. (a) Positions of allosteric sites (including cholesterol binding sites) identified in structures. The orthosteric site is marked by endogenous agonist epinephrine (EPI.). Positions of cholesterol are from a crystal structure in an inactive state (PDB ID: 2RH1 [6]). (b) PAM Cmpd-6FA and NAM AS408 in lipid interface at TM3/4/5 (PDB IDs: 6N48 [106] and 6OBA [107]). (c) Cytoplasmic NAM Cmpd-15PA compared to active state $\beta_{2}$ AR (PDB IDs: 5X7D [109] and 3SN6 [8]).

\subsection{PAM and NAM at Lipid Interface of TM3/4/5}

The arrangement of seven TM helices leads to a groove at the lipid interface formed by TM3/4/5 in all classes of GPCRs. In $\beta_{2} \mathrm{AR}$, both PAM and NAM binds in this groove are identified by crystal structures (Figure $7 \mathrm{~b}$ ). The PAM and the NAM locate at different heights and stabilize different states through specific interactions: the PAM Cmpd-6FA binds close to the cytoplasmic end and interacts with ICL2 and adjacent residues on TM3 and TM4 [110]. At this region, GPCRs interact with multiple segments of G $\alpha$, and Cmpd- 
6FA stabilizes conformation of the receptor. The NAM AS408 binds close to the center of the receptor and interacts with TM3 and TM5 [111]. AS408 forms a hydrogen bond to the main-chain $\mathrm{O}$ atom of V5.45, thus stabilizing the inactive conformation of TM5 and the P-I-F microswitch motif. Both the PAM and the NAM are selective for $\beta_{2} A R$ over $\beta_{1}$ AR; for positive modulating, two key residues (F3.52/L3.52 and K4.41/R4.41 in $\beta_{2} \mathrm{AR} / \beta_{1} \mathrm{AR}$ ) are identified. Since functions of ICL2 and TM5 are common in activation process of class A GPCRs, it is not surprising that allosteric modulators binding at the same site were also discovered in other receptors: PAMs AP8 [112] and Cpd-1 [113] of free fatty acid receptor 1, PAM LY3154207 [114] of dopamine receptor $\mathrm{D}_{1}$, and NAMs NDT9513727 [115,116] and avancopan [117] of C5a anaphylatoxin chemotactic receptor 1.

\subsection{NAM at Cytoplasmic Surface}

GPCRs use the cytoplasmic surface to interact with intracellular partners, including $G$ proteins and $\beta$-arrestins. Small molecules binding at this site were mainly discovered in chemokine receptors [116-119], while Cmpd-15PA in $\beta_{2} \mathrm{AR}$ [120] is the only case outside the chemokine subfamily (Figure 7c). All these small molecules are NAMs. Cmpd-15PA has little collisions with $G$ protein but stabilizes the inactive state of the receptor through extensive interactions with TM1, TM2, TM6, TM7, H8, and ICL1. Most notably, the hydrogen bond to T6.36 and $\pi-\pi$ interaction to $Y 7.53$ block the outward movement of TM6 and rearrangement of TM7. Although $\beta_{2} \mathrm{AR}$ and $\beta_{1} \mathrm{AR}$ only differ in one position (F1.60 in $\beta_{2} \mathrm{AR}$ and T1.60 in $\beta_{1} \mathrm{AR}$ ) among all residues interacting with Cmpd-15PA, the Cmpd-15 (parent compound of Cmpd-15PA with comparable effects) decreases the $\mathrm{EC}_{50}$ of orthosteric agonist in only $\beta_{2} \mathrm{AR}$ but not $\beta_{1} \mathrm{AR}$ [121].

\section{Structure-Based Ligand Discovery of Adrenergic Receptors}

\subsection{Virtual Screening with Molecular Docking}

Structure-based virtual screening can identify ligands with novel scaffolds and chemical types $[122,123]$. Since structures of $\beta_{2}$ AR are reported, new antagonists and agonists were discovered through virtual screening with molecular docking. Docking screening identified a new antagonist with benzhydrylpiperazine moiety having high sub-nM affinity $\left(K_{\mathrm{i}}=0.311 \mathrm{nM}\right)$ [124]. Screening of the lead-like subset of the ZINC database [125] identified 5 hit inverse agonists (among 25 tested compounds) with $K_{\mathrm{i}}<40 \mu \mathrm{M}$, while the strongest had $K_{\mathrm{i}}=9 \mathrm{nM}$ [126]. Using an active state structure, docking screening of the lead-like and fragment-like subsets of the ZINC database identified 6 agonists (4 full and 2 partial, among 22 tested compounds) [88].

\subsection{Rational Design}

Structures can guide modification of known ligands to achieve new function. Two designed $\beta$ agonists, analogs of BI-167107 and epinephrine but that can form disulfide bond, covalently bind to $\beta_{2} \mathrm{AR}$ with designed mutation $\mathrm{H} 2.64 \mathrm{C}$. They were obtained for the crystal structure in the agonist-bound inactive state [127] and nanobody-coupled active state [128], respectively. Adding of a methyl group to cyanopindolol (partial agonist of $\beta_{1} \mathrm{AR}$ and $\beta_{2} \mathrm{AR}$ ) at a position close to S5.46 further reduced its efficacy [77]. Inspired by structures of $\beta$ adrenergic receptors, five compounds based on atypical antipsychotic drug aripiprazole were designed and shown to have different effect on dopamine receptor $\mathrm{D}_{2}$ (one unbiased agonist, two arrestin-biased agonists, and two antagonists) [129].

\subsection{Predicting Actions of Ligands}

Molecular docking aims to identify compounds with high affinity but does not distinguish between an agonist and antagonist. Molecular interaction fingerprints derived from structures of a GPCR with various ligands have been developed to predict the actions of ligand. When only the first inactive $\beta_{2} A R$ structure was available, the molecular interaction fingerprint was generated based on docking poses of ligands [130]. The newest version of fingerprint was developed based on 31 structures of $\beta_{1} \mathrm{AR}$ and $\beta_{2} \mathrm{AR}$ [131]. Molecular 
docking followed by molecular interaction fingerprint (derived from 13 structures) screening identified 26 hit agonists (among 63 tested compounds) of $\beta_{2} \mathrm{AR}$ with $\mathrm{EC}_{50}<100 \mu \mathrm{M}$, while the strongest had $\mathrm{EC}_{50} 38 \mathrm{nM}$ [132].

\subsection{Accelerated Structure Determination}

Structure-based drug design against GPCRs relies on a large number of solved structures binding various ligands. Since 2018, many structures of active state GPCRs in functional complexes have been solved with the rapidly developed cryogenic electron microscopy (cryo-EM) technique. A remarkable case is dopamine receptor $\mathrm{D}_{1}$ : no structure was reported before February 2021, and then 11 structures were released within two months [113,133-135]. For adrenergic receptors, up to April 2021, a total of eight cryo-EM structures were published: one is arrestin-coupled $\beta_{1} A R$ and the others are $G$ protein-coupled (four $\beta_{2} A R, G_{s}[8,68,69]$; one $\beta_{1} A R, G_{s}[66]$; two $\alpha_{2 B} A R, G_{i}$ and $G_{o}$ [52]).

Crystallography is still powerful for the structural study of adrenergic receptors. Thermostabilized turkey $\beta_{1} A R$ can co-crystallize with small, fragment-like ligands [89]. Crystal structures of human $\beta_{1}$ AR were first reported in 2020, in both a nanobody-coupled active state and inactive state, exhibiting a detailed difference from turkey $\beta_{1} A R$ [43]. For $\beta_{2} \mathrm{AR}$, structures in complex with eight ligands were obtained using a newly developed transient ligand exchange method termed Complex-LCP (Crystallization of Membrane Proteins using transient Ligand EXchange in LCP). The Complex-LCP method relies on the serial femtosecond crystallography (SFX) data-collection approach, using extremely bright and short pulses generated by an X-ray free-electron laser (XFEL), thus collects data from small crystals at room temperature [75].

\section{Conclusions}

Structures of adrenergic receptors exhibited mechanisms of ligand-induced effects, including agonism/antagonism, partial agonism, and biased signaling. A preliminary picture of ligand function in $\beta$ adrenergic receptors was generated. The picture in $\alpha_{2}$ is still incomplete, while that in $\alpha_{1}$ remains to be uncovered. Interpreting of these mechanisms would help to discover new drugs with desired effects against adrenergic receptors.

Supplementary Materials: The following are available online at https:/ /www.mdpi.com/article/10 .3390/biom11070936/s1, Table S1: Representative ligands used in structural studies of adrenergic receptors.

Author Contributions: Investigation, Y.W. and L.Z.; writing-original draft preparation, Y.W.; writing-review and editing, S.Z.; visualization, Y.W.; supervision, S.Z.; funding acquisition, S.Z. All authors have read and agreed to the published version of the manuscript.

Funding: This research was funded by National Key R\&D Program of China, grant number 2018YFA0507000 (S.Z.) and National Natural Science Foundation of China, grant number 31971178 (S.Z.).

Institutional Review Board Statement: Not applicable.

Informed Consent Statement: Not applicable.

Data Availability Statement: Not applicable.

Conflicts of Interest: The authors declare no conflict of interest.

\section{References}

1. Bylund, D.B.; Eikenberg, D.C.; Hieble, J.P.; Langer, S.Z.; Lefkowitz, R.J.; Minneman, K.P.; Molinoff, P.B.; Ruffolo, R.R.; Trendelenburg, U. International Union of Pharmacology nomenclature of adrenoceptors. Pharmacol. Rev. 1994, 46, 121-136.

2. Ciccarelli, M.; Santulli, G.; Pascale, V.; Trimarco, B.; Iaccarino, G. Adrenergic receptors and metabolism: Role in develop-ment of cardiovascular disease. Front Physiol. 2013, 4, 265. [CrossRef]

3. Bylund, D.B. Adrenergic Receptors. In Encyclopedia of Biological Chemistry, 2nd ed.; Lennarz, W.J., Lane, M.D., Eds.; Academic Press: Waltham, MA, USA, 2013; pp. 57-60.

4. Farzam, K.; Kidron, A.; Lakhkar, A.D. Adrenergic Drugs; StatPearls: Treasure Island, FL, USA, 2021. 
5. Kobilka, B.K.; Dixon, R.A.; Frielle, T.; Dohlman, H.G.; Bolanowski, M.A.; Sigal, I.S.; Yang-Feng, T.L.; Francke, U.; Caron, M.G.; Lefkowitz, R.J. cDNA for the human beta 2-adrenergic receptor: A protein with multiple membrane-spanning do-mains and encoded by a gene whose chromosomal location is shared with that of the receptor for platelet-derived growth factor. Proc. Natl. Acad. Sci. USA 1987, 84, 46-50. [CrossRef] [PubMed]

6. Cherezov, V.; Rosenbaum, D.M.; Hanson, M.A.; Rasmussen, S.G.; Thian, F.S.; Kobilka, T.S.; Choi, H.J.; Kuhn, P.; Weis, W.I.; Kobilka, B.K.; et al. High-resolution crystal structure of an engineered human beta2-adrenergic G protein-coupled receptor. Science 2007, 318, 1258-1265. [CrossRef] [PubMed]

7. Rasmussen, S.G.; Choi, H.J.; Rosenbaum, D.M.; Kobilka, T.S.; Thian, F.S.; Edwards, P.C.; Burghammer, M.; Ratnala, V.R.; Sanishvili, R.; Fischetti, R.F.; et al. Crystal structure of the human beta2 adrenergic G-protein-coupled receptor. Nature 2007, 450, 383-387. [CrossRef] [PubMed]

8. $\quad$ Rasmussen, S.G.; DeVree, B.T.; Zou, Y.; Kruse, A.C.; Chung, K.Y.; Kobilka, T.S.; Thian, F.S.; Chae, P.S.; Pardon, E.; Calinski, D.; et al. Crystal structure of the beta2 adrenergic receptor-Gs protein complex. Nature 2011, 477, 549-555. [CrossRef] [PubMed]

9. Lohse, M.J.; Benovic, J.L.; Codina, J.; Caron, M.G.; Lefkowitz, R.J. beta-Arrestin: A protein that regulates beta-adrenergic re-ceptor function. Science 1990, 248, 1547-1550. [CrossRef] [PubMed]

10. Attramadal, H.; Arriza, J.; Aoki, C.; Dawson, T.; Codina, J.; Kwatra, M.; Snyder, S.; Caron, M.; Lefkowitz, R. Beta-arrestin2, a novel member of the arrestin/beta-arrestin gene family. J. Biol. Chem. 1992, 267, 17882-17890. [CrossRef]

11. Lee, Y.; Warne, T.; Nehme, R.; Pandey, S.; Dwivedi-Agnihotri, H.; Chaturvedi, M.; Edwards, P.C.; Garcia-Nafria, J.; Leslie, A.G.W.; Shukla, A.K.; et al. Molecular basis of beta-arrestin coupling to formoterol-bound beta1-adrenoceptor. Nature 2020, 583, 862-866. [CrossRef] [PubMed]

12. Hone, K.; Obika, K.; Foglar, R.; Tsujimoto, G. Selectivity of the imidazoline $\alpha$-adrenoceptor agonists (oxymetazoline and cirazoline) for human cloned $\alpha 1$-adrenoceptor subtypes. Br. J. Pharmacol. 1995, 116, 1611-1618. [CrossRef]

13. Jasper, J.R.; Lesnick, J.D.; Chang, L.K.; Yamanishi, S.S.; Chang, T.K.; Hsu, S.A.; Daunt, D.A.; Bonhaus, D.W.; Eglen, R.M. Ligand efficacy and potency at recombinant alpha2 adrenergic receptors: Agonist-mediated [35S]GTPgammaS binding. Biochem. Pharmacol. 1998, 55, 1035-1043. [CrossRef]

14. Hoffmann, C.; Leitz, M.R.; Oberdorf-Maass, S.; Lohse, M.J.; Klotz, K.N. Comparative pharmacology of human be-ta-adrenergic receptor subtypes-characterization of stably transfected receptors in CHO cells. Naunyn Schmiedebergs Arch. Pharmacol. 2004, 369, 151-159. [CrossRef]

15. Armstrong, J.F.; Faccenda, E.; Harding, S.D.; Pawson, A.J.; Southan, C.; Sharman, J.L.; Campo, B.; Cavanagh, D.R.; Alexander, S.P.H.; Davenport, A.P.; et al. The IUPHAR/BPS Guide to PHARMACOLOGY in 2020: Extending immunopharmacology content and introducing the IUPHAR/MMV Guide to MALARIA PHARMACOLOGY. Nucleic Acids Res. 2019, 48, D1006-D1021. [CrossRef]

16. Kooistra, A.J.; Mordalski, S.; Pándy-Szekeres, G.; Esguerra, M.; Mamyrbekov, A.; Munk, C.; Keserü, G.M.; Gloriam, E.D. GPCRdb in 2021: Integrating GPCR sequence, structure and function. Nucleic Acids Res. 2021, 49, D335-D343. [CrossRef]

17. Wishart, D.S.; Feunang, Y.D.; Guo, A.C.; Lo, E.J.; Marcu, A.; Grant, J.R.; Sajed, T.; Johnson, D.; Li, C.; Sayeeda, Z.; et al. DrugBank 5.0: A Major Update to the DrugBank Database for 2018. Nucleic Acids Res. 2018, 46, D1074-D1082. [CrossRef]

18. Surgand, J.-S.; Rodrigo, J.; Kellenberger, E.; Rognan, D. A chemogenomic analysis of the transmembrane binding cavity of human G-protein-coupled receptors. Proteins Struct. Funct. Bioinform. 2005, 62, 509-538. [CrossRef] [PubMed]

19. Katritch, V.; Cherezov, V.; Stevens, R.C. Structure-Function of the G Protein-Coupled Receptor Superfamily. Annu. Rev. Pharmacol. Toxicol. 2013, 53, 531-556. [CrossRef] [PubMed]

20. Flock, T.; Hauser, A.; Lund, N.; Gloriam, D.E.; Balaji, S.; Babu, M.M. Selectivity determinants of GPCR-G-protein binding. Nat. Cell Biol. 2017, 545, 317-322. [CrossRef] [PubMed]

21. Gloriam, D.E.; Foord, S.M.; Blaney, F.E.; Garland, S. Definition of the G Protein-Coupled Receptor Transmembrane Bundle Binding Pocket and Calculation of Receptor Similarities for Drug Design. J. Med. Chem. 2009, 52, 4429-4442. [CrossRef]

22. Ballesteros, J.A.; Weinstein, H. [19] Integrated methods for the construction of three-dimensional models and computational probing of structure-function relations in G protein-coupled receptors. In Methods in Neurosciences; Sealfon, S.C., Ed.; Academic Press: Waltham, MA, USA, 1995; Volume 25, pp. 366-428.

23. Peng, Y.; McCorvy, J.D.; Harpsøe, K.; Lansu, K.; Yuan, S.; Popov, P.; Qu, L.; Pu, M.; Che, T.; Nikolajsen, L.F.; et al. 5-HT2C Receptor Structures Reveal the Structural Basis of GPCR Polypharmacology. Cell 2018, 172, 719-730.e14. [CrossRef]

24. Roth, B.L.; Sheffler, D.J.; Kroeze, W.K. Magic shotguns versus magic bullets: Selectively non-selective drugs for mood dis-orders and schizophrenia. Nat. Rev. Drug Discov. 2004, 3, 353-359. [CrossRef]

25. Butini, S.; Nikolic, K.; Kassel, S.; Brückmann, H.; Filipic, S.; Agbaba, D.; Gemma, S.; Brogi, S.; Brindisi, M.; Campiani, G.; et al. Polypharmacology of dopamine receptor ligands. Prog. Neurobiol. 2016, 142, 68-103. [CrossRef]

26. Baker, J.G. The selectivity of beta-adrenoceptor agonists at human beta1-, beta2- and beta3-adrenoceptors. Br. J. Pharmacol. 2010, 160, 1048-1061. [CrossRef]

27. Lei, S. Cross interaction of dopaminergic and adrenergic systems in neural modulation. Int. J. Physiol. Pathophysiol. Pharmacol. 2014, 6, 137-142.

28. Lanau, F.; Zenner, M.T.; Civelli, O.; Hartman, D.S. Epinephrine and norepinephrine act as potent agonists at the recombi-nant human dopamine D4 receptor. J. Neurochem. 1997, 68, 804-812. [CrossRef] 
29. Sánchez-Soto, M.; Bonifazi, A.; Cai, N.S.; Ellenberger, M.P.; Newman, A.H.; Ferré, S.; Yano, H. Evidence for Noncanonical Neurotransmitter Activation: Norepinephrine as a Dopamine D2-Like Receptor Agonist. Mol. Pharmacol. 2016, 89, 457-466. [CrossRef] [PubMed]

30. Katoh, K.; Standley, D.M. MAFFT multiple sequence alignment software version 7: Improvements in performance and usability. Mol. Biol. Evol. 2013, 30, 772-780. [CrossRef] [PubMed]

31. Ring, A.M.; Manglik, A.; Kruse, A.C.; Enos, M.D.; Weis, W.I.; Garcia, K.C.; Kobilka, B.K. Adrenaline-activated structure of beta2-adrenoceptor stabilized by an engineered nanobody. Nature 2013, 502, 575-579. [CrossRef] [PubMed]

32. Insel, P.A. Adrenergic Receptors - Evolving Concepts and Clinical Implications. N. Engl. J. Med. 1996, 334, 580-585. [CrossRef]

33. Pooput, C.; Rosemond, E.; Karpiak, J.; Deflorian, F.; Vilar, S.; Costanzi, S.; Wess, J.; Kirk, K.L. Structural basis of the selectiv-ity of the beta(2)-adrenergic receptor for fluorinated catecholamines. Bioorg. Med. Chem. 2009, 17, 7987-7992. [CrossRef]

34. Suryanarayana, S.; Daunt, D.; Von Zastrow, M.; Kobilka, B. A point mutation in the seventh hydrophobic domain of the alpha 2 adrenergic receptor increases its affinity for a family of beta receptor antagonists. J. Biol. Chem. 1991, 266, 15488-15492. [CrossRef]

35. Hieble, J.P. Adrenergic Receptors. In Encyclopedia of Neuroscience; Squire, L.R., Ed.; Academic Press: Oxford, MS, USA, 2009; pp. 135-139.

36. Morales, D.R.; Jackson, C.; Lipworth, B.J.; Donnan, P.T.; Guthrie, B. Adverse respiratory effect of acute beta-blocker exposure in asthma: A systematic review and meta-analysis of randomized controlled trials. Chest 2014, 145, 779-786. [CrossRef]

37. Arch, J.R. Challenges in beta(3)-Adrenoceptor Agonist Drug Development. Ther. Adv. Endocrinol. Metab. 2011, 2, 59-64. [CrossRef]

38. Schwinn, D.A.; Price, D.T.; Narayan, P. $\alpha 1$-Adrenoceptor Subtype Selectivity and Lower Urinary Tract Symptoms. Mayo Clin. Proc. 2004, 79, 1423-1434. [CrossRef]

39. Uys, M.M.; Shahid, M.; Harvey, B.H. Therapeutic Potential of Selectively Targeting the $\alpha 2$ C-Adrenoceptor in Cognition, Depression, and Schizophrenia-New Developments and Future Perspective. Front. Psychiatry 2017, 8, 144. [CrossRef]

40. Hwa, J.; Graham, R.M.; Perez, D.M. Identification of Critical Determinants of $\alpha 1$-Adrenergic Receptor Subtype Selective Agonist Binding. J. Biol. Chem. 1995, 270, 23189-23195. [CrossRef]

41. Laurila, J.M.; Xhaard, H.; Ruuskanen, J.O.; Rantanen, M.J.; Karlsson, H.K.; Johnson, M.S.; Scheinin, M. The second extracellu-lar loop of alpha2A-adrenoceptors contributes to the binding of yohimbine analogues. Br. J. Pharmacol. 2007, 151, 1293-1304. [CrossRef]

42. Baker, J.G.; Proudman, R.G.; Hill, S.J. Salmeterol's extreme beta2 selectivity is due to residues in both extracellular loops and transmembrane domains. Mol. Pharmacol. 2015, 87, 103-120. [CrossRef] [PubMed]

43. Xu, X.; Kaindl, J.; Clark, M.J.; Hubner, H.; Hirata, K.; Sunahara, R.K.; Gmeiner, P.; Kobilka, B.K.; Liu, X. Binding pathway determines norepinephrine selectivity for the human beta1AR over beta2AR. Cell Res. 2021, 31, 569-579. [CrossRef] [PubMed]

44. Woo, A.Y.; Jozwiak, K.; Toll, L.; Tanga, M.J.; Kozocas, J.A.; Jimenez, L.; Huang, Y.; Song, Y.; Plazinska, A.; Pajak, K.; et al. Tyrosine 308 is necessary for ligand-directed Gs protein-biased signaling of beta2-adrenoceptor. J. Biol. Chem. 2014, 289, 19351-19363. [CrossRef] [PubMed]

45. Michino, M.; Beuming, T.; Donthamsetti, P.; Newman, A.H.; Javitch, J.A.; Shi, L. What Can Crystal Structures of Aminergic Receptors Tell Us about Designing Subtype-Selective Ligands? Pharmacol. Rev. 2015, 67, 198-213. [CrossRef]

46. Dean, I.J.; Reddivari, A.K.R. Alpha 1 Receptor Agonists; StatPearls Publishing: Treasure Island, FL, USA, 2021.

47. Nachawati, D.; Patel, J. Alpha Blockers; StatPearls Publishing: Treasure Island, FL, USA, 2021.

48. Giovannitti, J.A.; Thoms, S.M.; Crawford, J.J. Alpha-2 Adrenergic Receptor Agonists: A Review of Current Clinical Applications. Anesthesia Prog. 2015, 62, 31-38. [CrossRef]

49. Morales, A. Yohimbine in erectile dysfunction: The facts. Int. J. Impot. Res. 2000, 12, S70-S74. [CrossRef]

50. García-Sevilla, A.J.; Ventayol, P.; Pérez, V.; Rubovszky, G.; Puigdemont, D.; Ferrer-Alcón, M.; Andreoli, A.; Guimón, J.; Alvarez, E. Regulation of Platelet $\alpha 2 \mathrm{~A}$-Adrenoceptors, Gi Proteins and Receptor Kinases in Major Depression: Effects of Mirtazapine Treatment. Neuropsychopharmacology 2003, 29, 580-588. [CrossRef]

51. Dezsi, C.A.; Szentes, V. The Real Role of beta-Blockers in Daily Cardiovascular Therapy. Am. J. Cardiovasc. Drugs 2017, 17, 361-373. [CrossRef] [PubMed]

52. Yuan, D.; Liu, Z.; Kaindl, J.; Maeda, S.; Zhao, J.; Sun, X.; Xu, J.; Gmeiner, P.; Wang, H.-W.; Kobilka, B.K. Activation of the $\alpha 2 B$ adrenoceptor by the sedative sympatholytic dexmedetomidine. Nat. Chem. Biol. 2020, 16, 507-512. [CrossRef] [PubMed]

53. DeVree, B.; Mahoney, J.P.; Vélez-Ruiz, G.A.; Rasmussen, S.G.F.; Kuszak, A.; Edwald, E.; Fung, J.-J.; Manglik, A.; Masureel, M.; $\mathrm{Du}, \mathrm{Y}$;; et al. Allosteric coupling from G protein to the agonist-binding pocket in GPCRs. Nat. Cell Biol. 2016, 535, 182-186. [CrossRef]

54. Warne, T.; Edwards, P.C.; Doré, A.S.; Leslie, A.G.W.; Tate, C.G. Molecular basis for high-affinity agonist binding in GPCRs. Science 2019, 364, 775-778. [CrossRef]

55. Hua, T.; Vemuri, K.; Pu, M.; Qu, L.; Han, G.W.; Wu, Y.; Zhao, S.; Shui, W.; Li, S.; Korde, A.; et al. Crystal Structure of the Human Cannabinoid Receptor CB1. Cell 2016, 167, 750-762.e14. [CrossRef]

56. Hua, T.; Li, X.; Wu, L.; Iliopoulos_Tsoutsouvas, C.; Wang, Y.; Wu, M.; Shen, L.; Brust, C.A.; Nikas, S.P.; Song, F.; et al. Activation and Signaling Mechanism Revealed by Cannabinoid Receptor-Gi Complex Structures. Cell 2020, 180, 655-665.e18. [CrossRef] [PubMed]

57. Nojima, S.; Fujita, Y.; Kimura, K.T.; Nomura, N.; Suno, R.; Morimoto, K.; Yamamoto, M.; Noda, T.; Iwata, S.; Shigematsu, H.; et al. Cryo-EM Structure of the Prostaglandin E Receptor EP4 Coupled to G Protein. Structure 2021, 29, 252-260.e6. [CrossRef] 
58. Toyoda, Y.; Morimoto, K.; Suno, R.; Horita, S.; Yamashita, K.; Hirata, K.; Sekiguchi, Y.; Yasuda, S.; Shiroishi, M.; Shimizu, T.; et al. Ligand binding to human prostaglandin E receptor EP4 at the lipid-bilayer interface. Nat. Chem. Biol. 2019, 15, 18-26. [CrossRef] [PubMed]

59. Deluigi, M.; Klipp, A.; Klenk, C.; Merklinger, L.; Eberle, S.A.; Morstein, L.; Heine, P.; Mittl, P.R.E.; Ernst, P.; Kamenecka, T.M.; et al. Complexes of the neurotensin receptor 1 with small-molecule ligands reveal structural determinants of full, partial, and inverse agonism. Sci. Adv. 2021, 7, eabe5504. [CrossRef]

60. Fenalti, G.; Giguere, P.M.; Katritch, V.; Huang, X.P.; Thompson, A.A.; Cherezov, V.; Roth, B.L.; Stevens, R.C. Molecular control of delta-opioid receptor signalling. Nature 2014, 506, 191-196. [CrossRef] [PubMed]

61. Claff, T.; Yu, J.; Blais, V.; Patel, N.; Martin, C.; Wu, L.; Han, G.W.; Holleran, B.J.; Van der Poorten, O.; White, K.L.; et al. Elucidating the active delta-opioid receptor crystal structure with peptide and small-molecule agonists. Sci. Adv. 2019, 5, eaax9115. [CrossRef] [PubMed]

62. Cheng, R.K.; Segala, E.; Robertson, N.; Deflorian, F.; Doré, A.S.; Errey, J.C.; Fiez-Vandal, C.; Marshall, F.H.; Cooke, R.M. Structures of Human A 1 and A 2A Adenosine Receptors with Xanthines Reveal Determinants of Selectivity. Structure 2017, 25, 1275-1285.e4. [CrossRef] [PubMed]

63. Draper-Joyce, C.J.; Khoshouei, M.; Thal, D.M.; Liang, Y.-L.; Nguyen, A.T.N.; Furness, S.G.B.; Venugopal, H.; Baltos, J.-A.; Plitzko, J.M.; Danev, R.; et al. Structure of the adenosine-bound human adenosine A1 receptor-Gi complex. Nat. Cell Biol. 2018, 558, 559-563. [CrossRef]

64. Zhang, K.; Zhang, J.; Gao, Z.-G.; Zhang, D.; Zhu, L.; Han, G.W.; Moss, S.M.; Paoletta, S.; Kiselev, E.; Lu, W.; et al. Structure of the human P2Y12 receptor in complex with an antithrombotic drug. Nat. Cell Biol. 2014, 509, 115-118. [CrossRef] [PubMed]

65. Zhang, J.; Zhang, K.; Gao, Z.-G.; Paoletta, S.; Zhang, D.; Han, G.W.; Li, T.; Ma, L.; Zhang, W.; Müller, C.E.; et al. Agonist-bound structure of the human P2Y12 receptor. Nat. Cell Biol. 2014, 509, 119-122. [CrossRef]

66. Su, M.; Zhu, L.; Zhang, Y.; Paknejad, N.; Dey, R.; Huang, J.; Lee, M.Y.; Williams, D.; Jordan, K.D.; Eng, E.T.; et al. Structural Basis of the Activation of Heterotrimeric Gs-Protein by Isoproterenol-Bound beta1-Adrenergic Receptor. Mol. Cell 2020, 80, 59-71 e54. [CrossRef]

67. Warne, T.; Moukhametzianov, R.; Baker, J.G.; Nehme, R.; Edwards, P.C.; Leslie, A.G.; Schertler, G.F.; Tate, C.G. The structural basis for agonist and partial agonist action on a beta(1)-adrenergic receptor. Nature 2011, 469, 241-244. [CrossRef] [PubMed]

68. Zhang, Y.; Yang, F.; Ling, S.; Lv, P.; Zhou, Y.; Fang, W.; Sun, W.; Zhang, L.; Shi, P.; Tian, C. Single-particle cryo-EM structural studies of the beta2AR-Gs complex bound with a full agonist formoterol. Cell Discov. 2020, 6, 45. [CrossRef]

69. Yang, F.; Ling, S.; Zhou, Y.; Zhang, Y.; Lv, P.; Liu, S.; Fang, W.; Sun, W.; Hu, A.L.; Zhang, L.; et al. Different conformational responses of the $\beta 2$-adrenergic receptor-Gs complex upon binding of the partial agonist salbutamol or the full agonist isoprenaline. Natl. Sci. Rev. 2020, nwaa284. [CrossRef]

70. Masureel, M.; Zou, Y.; Picard, L.P.; van der Westhuizen, E.; Mahoney, J.P.; Rodrigues, J.; Mildorf, T.J.; Dror, R.O.; Shaw, D.E.; Bouvier, M.; et al. Structural insights into binding specificity, efficacy and bias of a beta2AR partial agonist. Nat. Chem. Biol. 2018, 14, 1059-1066. [CrossRef]

71. Warne, T.; Serrano-Vega, M.J.; Baker, J.G.; Moukhametzianov, R.; Edwards, P.C.; Henderson, R.; Leslie, A.G.; Tate, C.G.; Schertler, G.F. Structure of a beta1-adrenergic G-protein-coupled receptor. Nature 2008, 454, 486-491. [CrossRef] [PubMed]

72. Christopher, J.A.; Brown, J.; Dore, A.S.; Errey, J.C.; Koglin, M.; Marshall, F.H.; Myszka, D.G.; Rich, R.L.; Tate, C.G.; Tehan, B.; et al. Biophysical fragment screening of the beta1-adrenergic receptor: Identification of high affinity arylpiperazine leads using structure-based drug design. J. Med. Chem. 2013, 56, 3446-3455. [CrossRef] [PubMed]

73. Hanson, M.A.; Cherezov, V.; Griffith, M.T.; Roth, C.B.; Jaakola, V.-P.; Chien, E.Y.; Velasquez, J.; Kuhn, P.; Stevens, R.C. A Specific Cholesterol Binding Site Is Established by the $2.8 \AA$ A Structure of the Human $\beta 2$-Adrenergic Receptor. Structure 2008, 16, 897-905. [CrossRef] [PubMed]

74. Wacker, D.; Fenalti, G.; Brown, M.A.; Katritch, V.; Abagyan, R.; Cherezov, V.; Stevens, R.C. Conserved binding mode of human beta2 adrenergic receptor inverse agonists and antagonist revealed by X-ray crystallography. J. Am. Chem. Soc. 2010, 132, 11443-11445. [CrossRef] [PubMed]

75. Ishchenko, A.; Stauch, B.; Han, G.W.; Batyuk, A.; Shiriaeva, A.; Li, C.; Zatsepin, N.; Weierstall, U.; Liu, W.; Nango, E.; et al. Toward $\mathrm{G}$ protein-coupled receptor structure-based drug design using X-ray lasers. IUCrJ 2019, 6, 1106-1119. [CrossRef] [PubMed]

76. Moukhametzianov, R.; Warne, T.; Edwards, P.C.; Serrano-Vega, M.J.; Leslie, A.G.; Tate, C.G.; Schertler, G.F. Two distinct conformations of helix 6 observed in antagonist-bound structures of a beta1-adrenergic receptor. Proc. Natl. Acad. Sci. USA 2011, 108, 8228-8232. [CrossRef] [PubMed]

77. Sato, T.; Baker, J.; Warne, T.; Brown, G.A.; Leslie, A.G.; Congreve, M.; Tate, C.G. Pharmacological Analysis and Structure Determination of 7-Methylcyanopindolol-Bound beta1-Adrenergic Receptor. Mol. Pharmacol. 2015, 88, 1024-1034. [CrossRef] [PubMed]

78. Whalen, E.J.; Rajagopal, S.; Lefkowitz, R.J. Therapeutic potential of beta-arrestin- and G protein-biased agonists. Trends Mol. Med. 2011, 17, 126-139. [CrossRef]

79. Mangmool, S.; Parichatikanond, W.; Kurose, H. Therapeutic Targets for Treatment of Heart Failure: Focus on GRKs and beta-Arrestins Affecting betaAR Signaling. Front. Pharmacol. 2018, 9, 1336. [CrossRef]

80. Kang, Y.; Zhou, X.E.; Gao, X.; He, Y.; Liu, W.; Ishchenko, A.; Barty, A.; White, T.A.; Yefanov, O.; Han, G.W.; et al. Crystal structure of rhodopsin bound to arrestin by femtosecond X-ray laser. Nat. Cell Biol. 2015, 523, 561-567. [CrossRef] 
81. Yin, W.; Li, Z.; Jin, M.; Yin, Y.-L.; De Waal, P.W.; Pal, K.; Yin, Y.; Gao, X.; He, Y.; Gao, J.; et al. A complex structure of arrestin-2 bound to a G protein-coupled receptor. Cell Res. 2019, 29, 971-983. [CrossRef] [PubMed]

82. Huang, W.; Masureel, M.; Qu, Q.; Janetzko, J.; Inoue, A.; Kato, H.E.; Robertson, M.J.; Nguyen, K.C.; Glenn, J.S.; Skiniotis, G.; et al. Structure of the neurotensin receptor 1 in complex with beta-arrestin 1. Nature 2020, 579, 303-308. [CrossRef] [PubMed]

83. Staus, D.P.; Hu, H.; Robertson, M.J.; Kleinhenz, A.L.W.; Wingler, L.M.; Capel, W.D.; Latorraca, N.R.; Lefkowitz, R.J.; Skiniotis, G. Structure of the M2 muscarinic receptor-beta-arrestin complex in a lipid nanodisc. Nature 2020, 579, 297-302. [CrossRef] [PubMed]

84. Liu, J.J.; Horst, R.; Katritch, V.; Stevens, R.C.; Wuthrich, K. Biased signaling pathways in beta2-adrenergic receptor characterized by 19F-NMR. Science 2012, 335, 1106-1110. [CrossRef]

85. Wisler, J.W.; DeWire, S.M.; Whalen, E.J.; Violin, J.D.; Drake, M.T.; Ahn, S.; Shenoy, S.K.; Lefkowitz, R.J. A unique mechanism of beta-blocker action: Carvedilol stimulates beta-arrestin signaling. Proc. Natl. Acad. Sci. USA 2007, 104, 16657-16662. [CrossRef]

86. Galandrin, S.; Oligny-Longpre, G.; Bonin, H.; Ogawa, K.; Gales, C.; Bouvier, M. Conformational rearrangements and signaling cascades involved in ligand-biased mitogen-activated protein kinase signaling through the beta1-adrenergic receptor. Mol. Pharmacol. 2008, 74, 162-172. [CrossRef]

87. Rajagopal, S.; Ahn, S.; Rominger, D.H.; Gowen-MacDonald, W.; Lam, C.M.; DeWire, S.M.; Violin, J.D.; Lefkowitz, R.J. Quantifying Ligand Bias at Seven-Transmembrane Receptors. Mol. Pharmacol. 2011, 80, 367-377. [CrossRef]

88. Weiss, D.R.; Ahn, S.; Sassano, M.F.; Kleist, A.; Zhu, X.; Strachan, R.; Roth, B.L.; Lefkowitz, R.J.; Shoichet, B.K. Conformation guides molecular efficacy in docking screens of activated beta-2 adrenergic G protein coupled receptor. ACS Chem. Biol. 2013, 8 , 1018-1026. [CrossRef]

89. Warne, T.; Edwards, P.C.; Leslie, A.G.; Tate, C.G. Crystal structures of a stabilized beta1-adrenoceptor bound to the biased agonists bucindolol and carvedilol. Structure 2012, 20, 841-849. [CrossRef] [PubMed]

90. Rasmussen, S.G.; Choi, H.J.; Fung, J.J.; Pardon, E.; Casarosa, P.; Chae, P.S.; Devree, B.T.; Rosenbaum, D.M.; Thian, F.S.; Kobilka, T.S.; et al. Structure of a nanobody-stabilized active state of the beta(2) adrenoceptor. Nature 2011, 469, 175-180. [CrossRef] [PubMed]

91. Drake, M.T.; Violin, J.D.; Whalen, E.J.; Wisler, J.W.; Shenoy, S.K.; Lefkowitz, R.J. beta-arrestin-biased agonism at the beta2adrenergic receptor. J. Biol. Chem. 2008, 283, 5669-5676. [CrossRef] [PubMed]

92. Lukasheva, V.; Devost, D.; Le Gouill, C.; Namkung, Y.; Martin, R.D.; Longpre, J.M.; Amraei, M.; Shinjo, Y.; Hogue, M.; Lagace, M.; et al. Signal profiling of the beta1AR reveals coupling to novel signalling pathways and distinct phenotypic responses mediated by beta1AR and beta2AR. Sci. Rep. 2020, 10, 8779. [CrossRef]

93. Manglik, A.; Kim, T.H.; Masureel, M.; Altenbach, C.; Yang, Z.; Hilger, D.; Lerch, M.T.; Kobilka, T.S.; Thian, F.S.; Hubbell, W.L.; et al. Structural Insights into the Dynamic Process of beta2-Adrenergic Receptor Signaling. Cell 2015, 161, 1101-1111. [CrossRef] [PubMed]

94. Imai, S.; Yokomizo, T.; Kofuku, Y.; Shiraishi, Y.; Ueda, T.; Shimada, I. Structural equilibrium underlying ligand-dependent activation of beta2-adrenoreceptor. Nat. Chem. Biol. 2020, 16, 430-439. [CrossRef] [PubMed]

95. Lerch, M.T.; Matt, R.A.; Masureel, M.; Elgeti, M.; Kumar, K.K.; Hilger, D.; Foys, B.; Kobilka, B.K.; Hubbell, W.L. Viewing rare conformations of the beta2 adrenergic receptor with pressure-resolved DEER spectroscopy. Proc. Natl. Acad. Sci. USA 2020, 117, 31824-31831. [CrossRef]

96. Gregorio, G.G.; Masureel, M.; Hilger, D.; Terry, D.S.; Juette, M.; Zhao, H.; Zhou, Z.; Perez-Aguilar, J.M.; Hauge, M.; Mathiasen, S.; et al. Single-molecule analysis of ligand efficacy in beta2AR-G-protein activation. Nature 2017, 547, 68-73. [CrossRef]

97. Kofuku, Y.; Ueda, T.; Okude, J.; Shiraishi, Y.; Kondo, K.; Maeda, M.; Tsujishita, H.; Shimada, I. Efficacy of the beta(2)-adrenergic receptor is determined by conformational equilibrium in the transmembrane region. Nat. Commun. 2012, 3, 1045. [CrossRef] [PubMed]

98. Qu, L.; Zhou, Q.; Xu, Y.; Guo, Y.; Chen, X.; Yao, D.; Han, G.W.; Liu, Z.-J.; Stevens, R.C.; Zhong, G.; et al. Structural Basis of the Diversity of Adrenergic Receptors. Cell Rep. 2019, 29, 2929-2935.e4. [CrossRef]

99. Chen, X.; Xu, Y.; Qu, L.; Wu, L.; Han, G.W.; Guo, Y.; Wu, Y.; Zhou, Q.; Sun, Q.; Chu, C.; et al. Molecular Mechanism for Ligand Recognition and Subtype Selectivity of $\alpha 2$ C Adrenergic Receptor. Cell Rep. 2019, 29, 2936-2943.e4. [CrossRef] [PubMed]

100. Ruffolo, R.R.; Bondinell, W.; Hieble, J.P. .alpha.- and .beta.-Adrenoceptors: From the Gene to the Clinic. 2. Structure-Activity Relationships and Therapeutic Applications. J. Med. Chem. 1995, 38, 3681-3716. [CrossRef]

101. Ruffolo, R.R., Jr.; Spradlin, T.A.; Pollock, G.D.; Waddell, J.E.; Murphy, P.J. Alpha and beta adrenergic effects of the stereoi-somers of dobutamine. J. Pharmacol. Exp. Ther. 1981, 219, 447-452. [PubMed]

102. Pauwels, P.J.; Colpaert, F.C. Disparate ligand-mediated $\mathrm{Ca}(2+)$ responses by wild-type, mutant Ser(200)Ala and Ser(204)Ala alpha(2A)-adrenoceptor: G(alpha15) fusion proteins: Evidence for multiple ligand-activation binding sites. Br. J. Pharmacol. 2000, 130, 1505-1512. [CrossRef]

103. Sallinen, J.; Hoglund, I.; Engstrom, M.; Lehtimaki, J.; Virtanen, R.; Sirvio, J.; Wurster, S.; Savola, J.M.; Haapalinna, A. Pharmacological characterization and CNS effects of a novel highly selective alpha2C-adrenoceptor antagonist JP-1302. Br. J. Pharmacol. 2007, 150, 391-402. [CrossRef]

104. Sun, B.; Lockyer, S.; Li, J.; Chen, R.; Yoshitake, M.; Kambayashi, J.I. OPC-28326, a selective femoral vasodilator, is an al-pha2Cadrenoceptor-selective antagonist. J. Pharmacol. Exp. Ther. 2001, 299, 652-658.

105. Wootten, D.; Christopoulos, A.; Sexton, P.M. Emerging paradigms in GPCR allostery: Implications for drug discovery. Nat. Rev. Drug Discov. 2013, 12, 630-644. [CrossRef] 
106. Thal, D.M.; Glukhova, A.; Sexton, P.M.; Christopoulos, A. Structural insights into G-protein-coupled receptor allostery. Nat. Cell Biol. 2018, 559, 45-53. [CrossRef]

107. Wu, Y.; Tong, J.; Ding, K.; Zhou, Q.; Zhao, S. GPCR Allosteric Modulator Discovery. Adv. Exp. Med. Biol. 2019, 1163, $225-251$. [CrossRef]

108. Sarkar, P.; Chattopadhyay, A. Cholesterol interaction motifs in G protein-coupled receptors: Slippery hot spots? Wiley Interdiscip. Rev. Syst. Biol. Med. 2020, 12, e1481. [CrossRef]

109. Oswald, C.; Rappas, M.; Kean, J.; Doré, A.S.; Errey, J.C.; Bennett, K.; Deflorian, F.; Christopher, J.A.; Jazayeri, A.; Mason, J.S.; et al. Intracellular allosteric antagonism of the CCR9 receptor. Nat. Cell Biol. 2016, 540, 462-465. [CrossRef]

110. Liu, X.; Masoudi, A.; Kahsai, A.W.; Huang, L.Y.; Pani, B.; Staus, D.P.; Shim, P.J.; Hirata, K.; Simhal, R.K.; Schwalb, A.M.; et al. Mechanism of beta2AR regulation by an intracellular positive allosteric modulator. Science 2019, 364, 1283-1287. [CrossRef] [PubMed]

111. Liu, X.; Kaindl, J.; Korczynska, M.; Stossel, A.; Dengler, D.; Stanek, M.; Hubner, H.; Clark, M.J.; Mahoney, J.; Matt, R.A.; et al. An allosteric modulator binds to a conformational hub in the beta2 adrenergic receptor. Nat. Chem. Biol. 2020, 16, 749-755. [CrossRef]

112. Lu, J.; Byrne, N.; Wang, J.; Bricogne, G.; Brown, F.K.; Chobanian, H.R.; Colletti, S.L.; Di Salvo, J.; Thomas-Fowlkes, B.; Guo, Y.; et al. Structural basis for the cooperative allosteric activation of the free fatty acid receptor GPR40. Nat. Struct. Mol. Biol. 2017, 24, 570-577. [CrossRef] [PubMed]

113. Ho, J.D.; Chau, B.; Rodgers, L.; Lu, F.; Wilbur, K.L.; Otto, K.A.; Chen, Y.; Song, M.; Riley, J.P.; Yang, H.-C.; et al. Structural basis for GPR40 allosteric agonism and incretin stimulation. Nat. Commun. 2018, 9, 1-11. [CrossRef] [PubMed]

114. Zhuang, Y.; Krumm, B.; Zhang, H.; Zhou, X.E.; Wang, Y.; Huang, X.P.; Liu, Y.; Cheng, X.; Jiang, Y.; Jiang, H.; et al. Mecha-nism of dopamine binding and allosteric modulation of the human D1 dopamine receptor. Cell Res. 2021, 31, 593-596. [CrossRef] [PubMed]

115. Robertson, N.; Rappas, M.; Doré, A.S.; Brown, J.; Bottegoni, G.; Koglin, M.; Cansfield, J.; Jazayeri, A.; Cooke, R.M.; Marshall, F.H. Structure of the complement C5a receptor bound to the extra-helical antagonist NDT9513727. Nat. Cell Biol. 2018, 553, 111-114. [CrossRef] [PubMed]

116. Liu, H.; Kim, H.R.; Deepak, R.N.V.K.; Wang, L.; Chung, K.Y.; Fan, H.; Wei, Z.; Zhang, C. Orthosteric and allosteric action of the C5a receptor antagonists. Nat. Struct. Mol. Biol. 2018, 25, 472-481. [CrossRef]

117. Zheng, Y.; Qin, L.; Zacarías, N.V.O.; De Vries, H.; Han, G.W.; Gustavsson, M.; Dabros, M.; Zhao, C.; Cherney, R.J.; Carter, P.; et al. Structure of CC chemokine receptor 2 with orthosteric and allosteric antagonists. Nat. Cell Biol. 2016, 540, 458-461. [CrossRef]

118. Jaeger, K.; Brünle, S.; Weinert, T.; Guba, W.; Muehle, J.; Miyazaki, T.; Weber, M.; Furrer, A.; Haenggi, N.; Tetaz, T.; et al. Structural Basis for Allosteric Ligand Recognition in the Human CC Chemokine Receptor 7. Cell 2019, 178, 1222-1230.e10. [CrossRef]

119. Liu, K.; Wu, L.; Yuan, S.; Wu, M.; Xu, Y.; Sun, Q.; Li, S.; Zhao, S.; Hua, T.; Liu, Z.-J. Structural basis of CXC chemokine receptor 2 activation and signalling. Nat. Cell Biol. 2020, 585, 1-9. [CrossRef]

120. Liu, X.; Ahn, S.; Kahsai, A.W.; Meng, K.C.; Latorraca, N.R.; Pani, B.; Venkatakrishnan, A.J.; Masoudi, A.; Weis, W.I.; Dror, R.O.; et al. Mechanism of intracellular allosteric beta2AR antagonist revealed by X-ray crystal structure. Nature 2017, 548, 480-484. [CrossRef]

121. Ahn, S.; Kahsai, A.W.; Pani, B.; Wang, Q.T.; Zhao, S.; Wall, A.L.; Strachan, R.T.; Staus, D.P.; Wingler, L.M.; Sun, L.D.; et al. Al-losteric "beta-blocker" isolated from a DNA-encoded small molecule library. Proc. Natl. Acad. Sci. USA 2017, 114, 1708-1713. [CrossRef] [PubMed]

122. Shoichet, B.K.; Kobilka, B.K. Structure-based drug screening for G-protein-coupled receptors. Trends Pharmacol. Sci. 2012, 33, 268-272. [CrossRef]

123. Yang, D.; Zhou, Q.; Labroska, V.; Qin, S.; Darbalaei, S.; Wu, Y.; Yuliantie, E.; Xie, L.; Tao, H.; Cheng, J.; et al. G pro-tein-coupled receptors: Structure- and function-based drug discovery. Signal Transduct. Target. Ther. 2021, 6, 7. [CrossRef] [PubMed]

124. Topiol, S.; Sabio, M. Use of the X-ray structure of the Beta2-adrenergic receptor for drug discovery. Bioorg. Med. Chem. Lett. 2008, 18, 1598-1602. [CrossRef]

125. Irwin, J.; Shoichet, B.K. ZINC-A Free Database of Commercially Available Compounds for Virtual Screening. J. Chem. Inf. Model. 2005, 45, 177-182. [CrossRef] [PubMed]

126. Kolb, P.; Rosenbaum, D.M.; Irwin, J.J.; Fung, J.J.; Kobilka, B.K.; Shoichet, B.K. Structure-based discovery of beta2-adrenergic receptor ligands. Proc. Natl. Acad. Sci. USA 2009, 106, 6843-6848. [CrossRef]

127. Rosenbaum, D.M.; Zhang, C.; Lyons, J.A.; Holl, R.; Aragao, D.; Arlow, D.H.; Rasmussen, S.G.; Choi, H.J.; Devree, B.T.; Suna-hara, R.K.; et al. Structure and function of an irreversible agonist-beta(2) adrenoceptor complex. Nature 2011, 469, 236-240. [CrossRef] [PubMed]

128. Weichert, D.; Kruse, A.C.; Manglik, A.; Hiller, C.; Zhang, C.; Hübner, H.; Kobilka, B.K.; Gmeiner, P. Covalent agonists for studying G protein-coupled receptor activation. Proc. Natl. Acad. Sci. USA 2014, 111, 10744-10748. [CrossRef]

129. McCorvy, J.D.; Butler, K.V.; Kelly, B.; Rechsteiner, K.; Karpiak, J.; Betz, R.M.; Kormos, B.L.; Shoichet, B.K.; Dror, R.O.; Jin, J.; et al. Structure-inspired design of beta-arrestin-biased ligands for aminergic GPCRs. Nat. Chem. Biol. 2018, 14, 126-134. [CrossRef] [PubMed]

130. de Graaf, C.; Rognan, D. Selective structure-based virtual screening for full and partial agonists of the beta2 adrenergic re-ceptor. J. Med. Chem. 2008, 51, 4978-4985. [CrossRef] [PubMed] 
131. Kooistra, A.J.; Leurs, R.; de Esch, I.J.; de Graaf, C. Structure-Based Prediction of G-Protein-Coupled Receptor Ligand Func-tion: A beta-Adrenoceptor Case Study. J. Chem. Inf. Model. 2015, 55, 1045-1061. [CrossRef]

132. Kooistra, A.J.; Vischer, H.F.; McNaught-Flores, D.; Leurs, R.; de Esch, I.; De Graaf, C. Function-specific virtual screening for GPCR ligands using a combined scoring method. Sci. Rep. 2016, 6, 28288. [CrossRef]

133. Zhuang, Y.; Xu, P.; Mao, C.; Wang, L.; Krumm, B.; Zhou, X.E.; Huang, S.; Liu, H.; Cheng, X.; Huang, X.P.; et al. Structural in-sights into the human D1 and D2 dopamine receptor signaling complexes. Cell 2021, 184, 931-942 e918. [CrossRef]

134. Xiao, P.; Yan, W.; Gou, L.; Zhong, Y.-N.; Kong, L.; Wu, C.; Wen, X.; Yuan, Y.; Cao, S.; Qu, C.; et al. Ligand recognition and allosteric regulation of DRD1-Gs signaling complexes. Cell 2021, 184, 943-956.e18. [CrossRef]

135. Sun, B.; Feng, D.; Chu, M.L.; Fish, I.; Kelm, S.; Lebon, F.; Lovera, S.; Valade, A.; Wood, M.; Ceska, T.; et al. PDB 7JOZ. Available online: https:/ / www.rcsb.org/structure/7JOZ (accessed on 24 May 2021). 